\title{
The paleoenvironmental context of Toarcian vertebrate-yielding shales of southern France (Hérault)
}

Brahimsamba Bomou ${ }^{1 *}$, Guillaume Suan², Jan Schlögl ${ }^{3}$, Anne-Sabine Grosjean ${ }^{4}$, Baptiste Suchéras-Marx ${ }^{5}$, Thierry Adatte ${ }^{1}$, Jorge Spangenberg ${ }^{6}$, Stéphane Fouché7, Axelle Zacai ${ }^{8}$, Corentin Gibert ${ }^{8}$, Jean-Michel Brazier ${ }^{9}$, Vincent Perrier $^{2}$, Peggy Vincent ${ }^{10}$, Kévin Janneau ${ }^{11} \&$ Jeremy E. Martin²

${ }^{1}$ Institute of Earth Sciences (ISTE), University of Lausanne, Geopolis, CH-1015 Lausanne, Switzerland.

${ }^{2}$ Université de Lyon, UCBL, ENSL, CNRS, UMR 5276 LGL-TPE, 69622 Villeurbanne, France.

${ }_{3}^{3}$ Department of Geology and Paleontology, Comenius University, Mlynska dolina G, 84215, Bratislava, Slovakia.

${ }^{4}$ Paleorhodania, 69006 Lyon - France.

${ }^{5}$ Aix Marseille Univ, CNRS, IRD, INRAE, Coll France, CEREGE, Aix-en-Provence, France.

${ }^{6}$ Institute of Earth Surface Dynamics (IDYST), University of Lausanne, Geopolis, CH-1015 Lausanne, Switzerland.

${ }^{7}$ Musée de Lodève, 1 place Francis Morand, 34700, Lodève, France.

${ }^{8}$ PALEVOPRIM Laboratoire Paléontologie Evolution Paléoécosystèmes Paléoprimatologie UMR CNRS 7262, Université de Poitiers, 86073 Poitiers Cedex 9, France.

${ }^{9}$ Institute of Applied Geosciences, Graz University of Technology, Rechbauerstrasse 12, A-8010 Graz, Austria.

${ }^{10}$ Sorbonne Université (CNRS-MNHN-UPMC) - Muséum national d'Histoire naturelle, Département Origines et Evolution, UMR CNRS-MNHN-UPMC 7207, Centre de Recherche en Paléontologie-Paris (CR2P), 57, rue Cuvier - 75231 Paris Cedex 05, France.

${ }^{11}$ Université de Strasbourg (UNISTRA), Jardin des sciences, 12 Rue de l'Université, 67000 Strasbourg, France.

ORCID : 0000-0002-7600-5276

Correspondence: brahimsamba.bomou@gmail.com

\section{Abstract}

The Early Jurassic was marked by several episodes of rapid climate changes and environmental perturbation. These changes culminated during the Toarcian Oceanic Anoxic Event (T-OAE), an episode of global warming that led to the widespread deposition of organic-rich shales. The Toarcian shales of NW Europe have also yielded exceptionally preserved fossils of marine vertebrate and invertebrates, but the potential links between the occurrences of these exceptionally preserved fossils and the T-OAE remain poorly investigated. Paleontological excavations realised in Toarcian strata near 
Lodève (Hérault, S France) have yielded several specimens of marine vertebrates and abundant invertebrate fauna. We have developed a multi-proxy approach (ammonite biostratigraphy, XRD-bulk mineralogy, Rock-Eval pyrolysis, stable isotopes, phosphorus and mercury contents) to replace these findings in a well-defined temporal and paleoenvironmental context, and hence constrain the factors that led to their remarkable preservation. The T-OAE interval, unambiguously identified at the base of the Toarcian organic-rich shales by a 5 permil negative carbon isotope excursion (CIE), records higher mercury fluxes that supports a causal link with intense volcanic activity of the Karoo-Ferrar large igneous province. This interval is very condensed and unfossiliferous, and is characterised by a marked decrease in oxygen isotope values and $\mathrm{Sr} / \mathrm{Ba}$ ratios, suggesting deposition under abnormally low salinity conditions. Our data show that the deposition of the vertebrate-yielding horizons post-dated the T-OAE by several hundreds of kyrs, and took place during a prolonged period of widespread oxygen-deficiency and elevated carbon burial. Our results indicate that the unusual richness in vertebrates of the studied site can be explained by a combination of regional factors such as warming-induced, prolonged seafloor anoxia, and more local factors, such as extreme condensation due to reduced dilution by carbonate and detrital input.

\section{Introduction}

The Mesozoic Era was punctuated by several oceanic anoxic events (OAEs), which were associated with global environmental changes and short-lived episodes of "black shales" deposition (Schlanger and Jenkyns, 1976). The oldest known of these OAE is the Toarcian oceanic anoxic event (T-OAE; Lower Jurassic, $183 \mathrm{Ma}$ ago), which is considered as one of the most severe environmental perturbation of the Mesozoic. The T-OAE interval included marine invertebrate mass extinction, strong biotic changes affecting benthic and pelagic organisms, marked changes in climatic and hydrological cycles and widespread organic matter deposition at a global scale (Jenkyns, 1988; Cecca and Macchioni, 2004; Gómez et al., 2008; Suan et al., 2008, 2011; Mattioli et al., 2009; Danise et al., 2015; Percival et al., 2016; Slater et al., 2019; Them II et al., 2017b).

The onset of the T-OAE is marked by a $>3 \%$ carbon isotope excursion (CIE) that has been documented in marine carbonate minerals as well as in marine and terrestrial organic matter in numerous globally distributed sites (Izumi et al., 2018; Suan et al., 2011; Them II et al., 2017a; Ullmann et al., 2020; van de Schootbrugge et al., 2020). 
Existing high-precision $\mathrm{U}-\mathrm{Pb}$ dating and integrated bio- and magneto-stratigraphy indicate the T-OAE negative CIE occurred at a time of intense volcanic activity in the Karoo-Ferrar large igneous province (LIP) (Pálfy et al., 2000; Sell et al., 2014; Burgess et al., 2015; Ivanov et al., 2017). Following the recent U-Pb ages, the Ferrar LIP volcanism started at $182.779 \pm 0.033 \mathrm{Ma}$, with a duration of $349 \pm 49 \mathrm{kyr}$ (Burgess et al., 2015; Ivanov et al., 2017) and the Karoo LIP magmatism began at least at $183.246 \pm 0.045 \mathrm{Ma}$ (Burgess et al., 2015) with sill ages of 183.01-181.31 Ma (Sell et al., 2014), suggesting that the Karoo-Ferrar could be related to the T-OAE CIE which start at 183.1 Ma (Sell et al., 2014). However not yet evidence to a relationship with the older CIA of the Pl-To boundary, even if Ar-Ar ages suggest an older age for the Karoo Ferrar LIP (between 186 and $182 \mathrm{Ma}$; Jourdan et al., 2008). The CIE has been therefore widely interpreted to reflect the massive injection of isotopically light carbon in a roughly direct relationship with the Karoo-Ferrar LIP activity (Pálfy and Smith, 2000; Wignall et al., 2005; Suan et al., 2008; Burgess et al., 2015; Percival et al., 2015; Ikeda et al., 2018). The CIE may thus reflect the release of volcanogenic $\mathrm{CO}_{2}$ produced in the Karoo-Ferrar LIP, or more indirectly, the massive injection of methane derived from contact metamorphism by sills (Svensen et al., 2007) and/or released from marine gas hydrate dissociation as a feedback to initial volcanic-induced warming (Hesselbo et al., 2000), or from wetlands and permafrost (Ruebsam et al., 2019). Additional evidence for the implication of volcanic activity has been provided by sedimentary mercury ( $\mathrm{Hg}$ ) records, which show a sharp rise at the onset of the T-OAE negative CIE in several sites (Percival et al., 2015; Fantasia et al., 2019), although complications linked to changing organic matter input have been recognised (Fantasia et al., 2019; Them II et al., 2019).

Regardless of its exact source, the consensus is that the massive input of greenhouse gases initiated a suite of severe environmental feedbacks that were ultimately detrimental to marine fauna. Greenhouse-driven warming (Ruebsam et al., 2020) is considered to have increased, through higher continental weathering and runoff, freshwater and nutrient input to sea waters, enhancing vertical stratification and productivity export (Dera and Donnadieu, 2012; French et al., 2014; Montero-Serrano et al., 2015; Percival et al., 2016; Fantasia et al., 2018b). These conditions in turn decreased the renewal of dissolved oxygen (Ruvalcaba Baroni et al., 2018) and increased its consumption through higher respiration rates, promoting widespread anoxia and the 
production of hydrogen sulphide $\left(\mathrm{H}_{2} \mathrm{~S}\right)$ by sulphate-reducing bacteria in bottom-waters (Schouten et al., 2000; French et al., 2014).

The combination of these hostile conditions (warmer seawater, low salinity, euxinia) not only triggered the extinction of several marine invertebrate but also favoured the exceptional preservation of fossil specimens, which are abundant in many sites of early Toarcian age in NW Europe and Canada (Vincent et al., 2013; Maxwell and Vincent, 2016; Martindale et al., 2017; Martin et al., this volume). These specimens are fundamental to improve our understanding of the paleobiology and paleodiversity of the early Jurassic marine fauna, as exemplified by the large number of historically important 'skin ichthyosaur' specimens found in Toarcian strata from SW Germany (Martill, 1993; Lindgren et al., 2018). The end of this event was likely facilitated by the resulting increase in organic carbon burial, which sequestered massive amounts of ${ }^{12} \mathrm{C}$-depleted carbon, as reflected by the positive CIE following the negative CIE in almost all published records (Ullmann et al., 2020). Nevertheless, the occurrence of thick organic-rich deposits in many NW European and Siberian sites above the negative CIE indicates that anoxic conditions persisted for a much longer time interval in sites bordering the large continental masses of the Eurasia (Röhl et al., 2001; Suan et al., 2011, 2018; Slater et al., 2019).

Despite the large number of multidisciplinary investigations published on the TOAE over the last decades, the link between environmental changes and the occurrence of exceptionally preserved fossils has been poorly investigated. In particular, it is unclear whether the preservation of articulated vertebrate specimens was restricted to the negative CIE interval or may cover a wider stratigraphic interval.

The Lower Jurassic stratigraphic sequence of the Grands Causses basin, located in the Central-South France, has been well-documented in several studies (e.g., Trümpy, 1983; Guex et al., 2001; Morard et al., 2003; Morard, 2004), with a couple of sections benefiting from high resolution biostratigraphic and geochemical framework (Morard et al., 2003; Mailliot et al., 2009; Harazim et al., 2013; Fonseca et al., 2018). Regionally, remarkably well-preserved and articulated marine vertebrate skeletons have been recovered from these deposits (Sciau et al. 1990; Sander and Bucher, 1993; Bardet et al., 1999). Given the abundance and quality of preservation of marine reptiles from coeval deposits from other European sections (e.g., Urlichs et al., 1994), additional finds were to be expected in this Early Jurassic basin from southern France. Paleontological 
excavations at the Roqueredonde section (Hérault; France) during field campaigns in 2017-2020, allowed the discovery of several marine vertebrates' specimens. These newly discovered specimens are partly or entirely preserved in anatomical connection and include a partial ichthyosaur skeleton with soft tissues as well as a complete, $>4$ mlong thalattosuchian (i.e. a longirostrine marine crocodile).

In this study, a multi-proxy approach including high-resolution ammonite biostratigraphy, bulk and clay mineralogy and geochemistry (stable isotopes, Rock-Eval pyrolysis, phosphorus, major and trace elements and mercury contents) is used to better constrain the paleoenvironmental and paleoclimatic conditions that led to the remarkable preservation of these marine vertebrates. The main aims of this study were to: (1) characterise the paleoclimatic and paleoenvironmental conditions in the Grands Causses Basin through the early Toarcian time interval that permitted the deposition of widespread well-preserved marine vertebrates; (2) better constrain the expression of the T-OAE, based on the organic matter preservation and fluxes across the Grands Causses basin; (3) and complement the $\mathrm{Hg}$ records during the T-OAE in the NW European Shelf.

\section{Geological setting and stratigraphy}

The Roqueredonde section is located in the Central-South France in South edge of the Grands Causses basin on the Languedoc High (Fig. 1A). The studied site is located on a private land and its exact location (GPS coordinates) is not given here to prevent fossil extraction by unauthorized individuals. However, inquiries about the site for scientific investigation can be directed to the Museum of Lodève. This area consists of several shallow marine epicontinental basins (Fig. 1B) interconnected through paleo-highs (Thierry et al., 2000). During the Early Jurassic, the Grands Causses basin was located at a paleolatitude encompassed between 25 and $30^{\circ} \mathrm{N}$ (Fig. 1B) and bordered by the crystalline Hercynian units of Massif Central to the North, the Montagne Noire to the South, the Rouergue to the West and the Cevennes to the East (Trümpy, 1983). The basin is structured by Hercynian NNE-SSW normal faults that were reactivated during the Early Jurassic (Arthaud and Matte, 1975) and controlled its morphology. Due to differential subsidence across the basin, the spatial thickness of the early Jurassic deposits strongly varies from the depocenter to the margin (Languedoc High), resulting in repeated hiatuses (Trümpy, 1983). The Roqueredonde section exposes three marine 
intervals deposited in shallow marine environment on the Languedoc High: (1) the Marnes de Villeneuves Formation (Fm) deposited during the Late Pliensbachian; (2) the Lower Toarcian Schistes carton Fm. and (3) the Lower to Upper Toarcian Marnes de Fontaneilles Fm. (Trümpy, 1983).
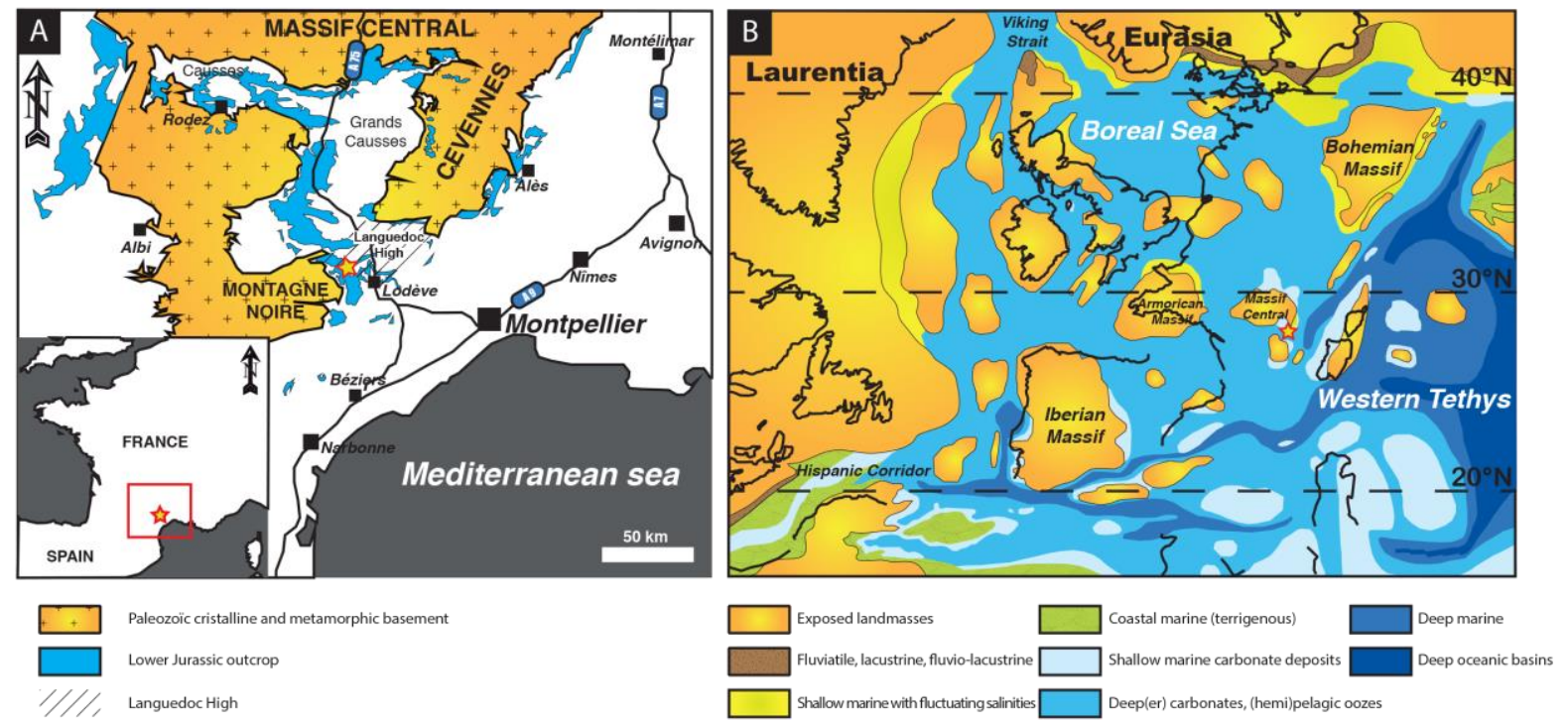

Figure 1: (A) Location of the Roqueredonde section, South France, and location of Lower Jurassic outcrop (in blue). (B) Paleogeographic location of the studied section in the western Tethys (after Thierry, 2000).

\section{Material and methods}

A total of 92 rock samples were collected from the Upper Pliensbachian-Middle Toarcian interval in the Roqueredonde section. GPS coordinates of the study site have been recorded and are curated with the specimens/samples under study in the collections of the Museum of Lodève. Bulk-rock powders were obtained using a mechanical agate crusher from hand samples, avoiding zones of alteration and calcite recrystallisation.

Stable carbon and oxygen isotope analyses were performed using a Thermo Fisher Scientific GasBench II preparation device interfaced to a Thermo Fisher Scientific Delta V continuous flow isotope ratio mass spectrometer (IRMS) at the Institute of Earth Surface Dynamics of the University of Lausanne (IDYST-UNIL). The stable isotope composition of carbon and oxygen $\left(\delta^{13} \mathrm{C}\right.$ and $\delta^{18} \mathrm{O}$ values) are reported in permil (\%o) relative to the Vienna Pee Dee Belemnite limestone (VPDB) standard. Analytical precision $(2 \sigma)$ is better than $\pm 0.05 \%$ o for $\delta^{13} \mathrm{C}$ and $\pm 0.1 \%$ or for $\delta^{18} 0$. 
The whole-rock mineralogy was determined at the Institute of Earth Sciences of the University of Lausanne (ISTE-UNIL) using a X-TRA Thermo-ARL Diffractometer following the Kübler's procedure (Kübler, 1987; Adatte et al., 1996). Homogenous powders, obtained by crushing (particle sizes $<40 \mu \mathrm{m}$ ), were pressed (20 bars) in a powder holder covered with a blotting paper and analysed by XRD. The error varied between $5-10 \%$ for the phyllosilicates and 5\% for grain minerals.

The amount and type of organic matter were determined by Rock-Eval pyrolysis at the ISTE-UNIL using a Rock-Eval 6 following the procedure of Espitalié et al. (1985) and Behar et al. (2001). The parameters determined are: the total organic carbon (TOC) content is expressed in weight (wt.\%); the hydrogen index (HI = $\left.\mathrm{S}_{2} / \mathrm{TOC} \times 100\right)$ in $\mathrm{mg}$ hydrocarbons per $\mathrm{g}$ of TOC; the oxygen index (OI = $\left.\mathrm{S}_{3} / \mathrm{TOC} \times 100\right)$ in $\mathrm{mg} \mathrm{CO}_{2}$ per $\mathrm{g}$ of TOC. The calibration was performed with the IFP 160000 standard (French Institute of Petroleum), and the precision was $<0.1 \%$.

The mercury $(\mathrm{Hg})$ content was measured on bulk rock powdered sample using a Zeeman R-915F (Lumex, St-Petersburg, Russia) high-frequency atomic absorption spectrometer set in Mode $1\left(700^{\circ} \mathrm{C}\right.$ ) at the ISTE-UNIL. The GSD-11 (Chinese alluvium; [Hg] $72 \pm 6 \mathrm{ppb}$ ) reference material was used for calibration and all measurements were duplicated. Due to the high affinity of $\mathrm{Hg}$ for organic carbon, the measured values were normalised to TOC content (e.g., Grasby et al., 2013).

Total phosphorus content was determined by the ascorbic acid molybdate blue method (Eaton et al., 1995) at the ISTE-UNIL. The intensity of the blue colour, depending to the phosphorus concentration, was quantified with an UV/Vis Perkin Elmer Lambda 25 spectrophotometer. The concentration of $\mathrm{PO}_{4} \mathrm{in} \mathrm{mg} / \mathrm{L}$ was obtained by calibration with internal standard solutions with a precision better than $5 \%$.

Whole-rock major element contents $\left(\mathrm{SiO}_{2}, \mathrm{TiO}_{2}, \mathrm{Al}_{2} \mathrm{O}_{3}, \mathrm{Fe}_{2} \mathrm{O}_{3}, \mathrm{MnO}, \mathrm{MgO}, \mathrm{CaO}\right.$, $\mathrm{Na}_{2} \mathrm{O}, \mathrm{K}_{2} \mathrm{O}, \mathrm{Cr}_{2} \mathrm{O}_{3}$, and $\mathrm{NiO}$ ) were quantified by X-ray fluorescence spectrometry (XRF) at the ISTE-UNIL, using a wavelength-dispersive PANalytical AxiosmAX spectrometer fitted with a $4 \mathrm{~kW} \mathrm{Rh}$ X-ray tube. The analyses were performed on fused-disks prepared from $1.2 \mathrm{~g}$ of calcined sample powder mixed with lithium-tetraborat (1:5 mixture). The XRF calibrations are based on 21 international silicate rock reference materials. Detection limits are comprised between 20 to 80 ppm depending on the considered element. 


\section{Roqueredonde section, France}

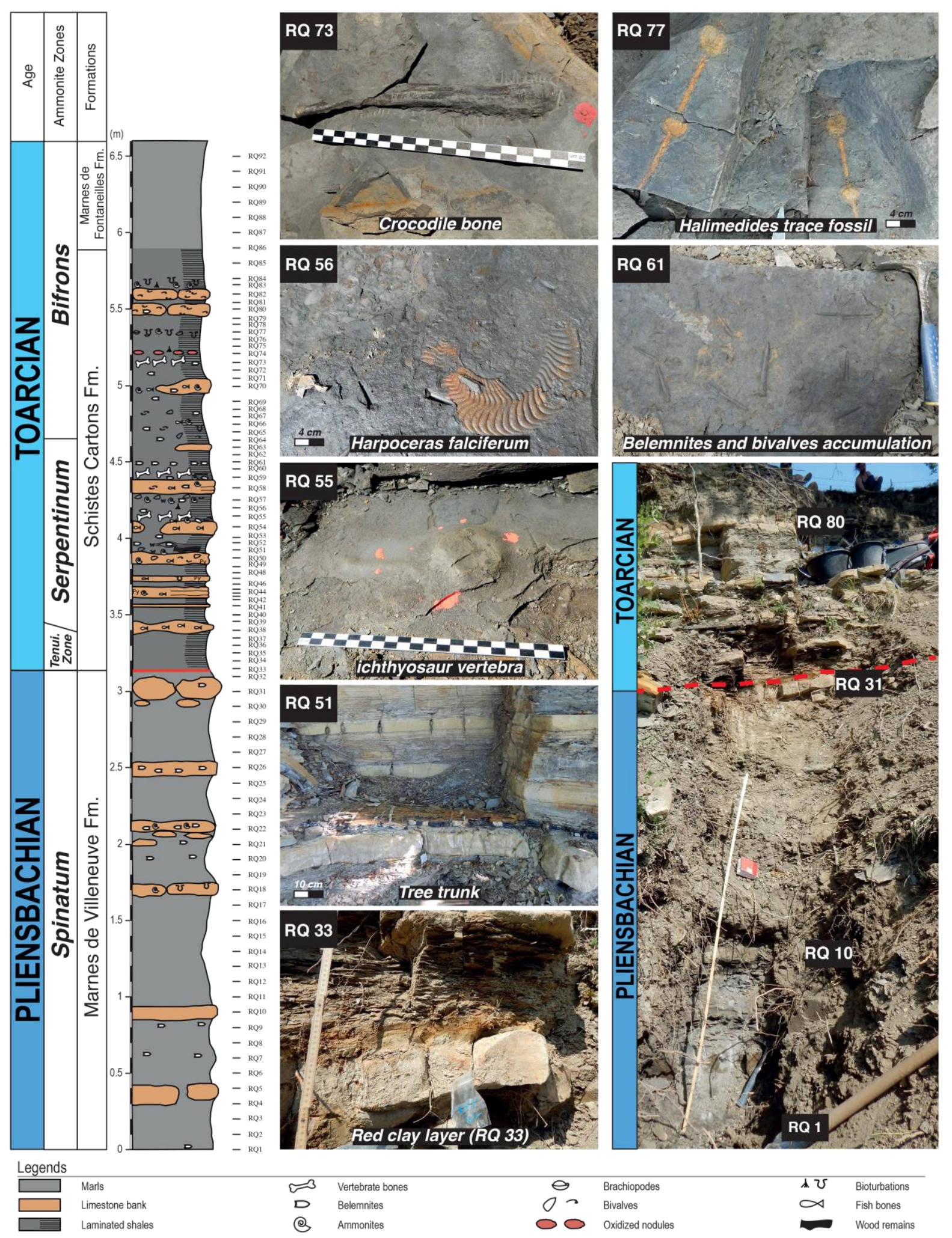

Figure 2: Lithology of the Roqueredonde section. Locations of the pictures are indicated by the sample number. 
Trace elements analyses (V, Cr, Mn, Co, $\mathrm{Ni}, \mathrm{Cu}, \mathrm{Zn}, \mathrm{As}, \mathrm{Sr}, \mathrm{Zr}, \mathrm{Mo}, \mathrm{Ba}, \mathrm{U}$ ) were conducted on disks obtained by pressing $8 \mathrm{~g}$ of sample powder mixed with Hoechstwax-C. The trace element calibrations are based on synthetic standards and international silicate rock reference materials. Detection limits of traces depend on each element in a range of 1 to $7 \mathrm{ppm}$.

Based on major-element concentrations, two weathering indices were calculated to characterize detrital sources and paleoclimate conditions (Nesbitt and Young, 1982; Fedo et al., 1995, 1997; Yan et al., 2010). The chemical index of alteration (CIA; Nesbitt and Young, 1982) was used to monitor the weathering of unstable minerals, while the weathering index of Parker (WIP; Parker, 1970) was used to evaluate the degree of chemical weathering by tracing the mass transfer of labile elements such as alkali and alkaline earth elements (e.g., Price and Vebel, 2003; Gertsch et al., 2011). To use these indices in carbonate rocks, the molar proportion of $\mathrm{CaO}$ must be restricted to that derived from silicate mineral and is noted $\mathrm{CaO}^{*}$ (Nesbitt and Young, 1982, 1989; Yan et al., 2010). The initial formula was consequently corrected giving the formula (1), in which $\mathrm{CaO}$ was replaced by $\mathrm{Na}_{2} \mathrm{O}$ (McLennan, 1993).

The CIA is expressed as (in molar proportion):

(1) $\mathrm{CIA}=\mathrm{Al}_{2} \mathrm{O}_{3} \times 100 /\left(\mathrm{Al}_{2} \mathrm{O}_{3}+\mathrm{CaO}^{*}+\mathrm{Na}_{2} \mathrm{O}+\mathrm{K}_{2} \mathrm{O}\right)$

(the $\mathrm{CaO}^{*}$ content is replaced by $\mathrm{Na}_{2} \mathrm{O}$ content)

The WIP is expressed as (in molar proportion):

(2) $\mathrm{WIP}=100 \times\left[\left(2 \mathrm{xNa}_{2} \mathrm{O} / 0.35\right)+(\mathrm{MgO} / 0.9)+\left(2 \mathrm{xK}_{2} \mathrm{O} / 0.25\right)+\left(\mathrm{CaO}^{*} / 0.7\right)\right]$

(the $\mathrm{CaO}^{*}$ content is replaced by $\mathrm{Na}_{2} \mathrm{O}$ content)

\section{Results}

\section{Lithology and faunal content}

The Marnes de Villeneuve Fm., deposited during the Late Pliensbachian, are characterised by grey marl deposits containing concretionary limestone beds (Fig. 2; Trümpy, 1983; Morard et al., 2004). Both lithologies contain belemnites and ammonites (Pleuroceras) and are strongly bioturbated. The Pliensbachian-Toarcian (Pl-To) transition at $3.15 \mathrm{~m}$ is marked by a red clay layer (Fig. 2; RQ-33) that correlates with a hard-ground surface enriched in oxidised and phosphatised material recognised in numerous sections in the Grands Causses Basin (Trümpy, 1983; Morard et al., 2003; Mailliot et al., 2009). Above, three meters of dark laminated shale beds of the Lower 
Toarcian Schistes carton Fm. (Fig. 2) alternate with limestone beds and concretionary beds. Some of these beds contain some coarser material. The conspicuous concretionary limestone bed enriched in fish remains occurring at $3.4 \mathrm{~m}$ (Fig. 2; RQ-38) is here attributed to the "Leptolepis bed" (Trümpy, 1983) found throughout the basin. The interval from 3.15 to 3.9 m yields abundant fish debris, bivalve and ammonite shells but is totally devoid of belemnite rostra. The interval above $3.9 \mathrm{~m}$ yielded numerous ammonites (Phylloceras, Dactylioceras, Harpoceras...), belemnites, bivalves, fish remains, and larger vertebrate bones (Fig. 2). Bioturbations attributed to Halimedides occur between 5.3 and $5.7 \mathrm{~m}$ in the bifrons Zone. Following the definition by Uchman (1998, 1999), the identified traces show a high degree of variability in the ichnological features. The uppermost part of the section is characterised by marl deposits from $5.9 \mathrm{~m}$ toward the top and belong to the Marnes de Fontaneilles Fm.

\section{Biostratigraphy}

The biostratigraphy is based on ammonites: amaltheids and arieticeratids in the uppermost Pliensbachian and mainly harpoceratids and hildoceratids in the Lower and Middle Toarcian. Lower part of the section, between 0.3 and $3.1 \mathrm{~m}$ (samples RQ-4 to RQ31, Marnes de Villeneuves Fm.) yielded mainly numerous Pleuroceras of the spinatum Zone. Ammonites come exclusively from the limestone or marly limestone beds. In samples RQ-22 and RQ-31 the Pleuroceras solare and/or P. spinatum are associated with Emaciaticeras. In the Grands Causses Basin this taxon is known only from the late spinatum Zone, hawskerense Subzone (Meister, 1989). Moreover, the uppermost limestone bed (RQ-31) yielded also a Tauromeniceras sp., morphologically close to $T$. nerinea, which indicates the terminal part of the spinatum Zone. The occurrence of Tiltoniceras antiquum between 3.15 and $3.3 \mathrm{~m}$ (base of the Schistes carton Fm.) suggests the presence of the upper part of tenuicostatum Zone (semicelatum Subzone) at Roqueredonde, which is consistent with the occurrences of specimens referred to this taxon at the base of the Schistes carton Fm at Saint-Paul-des-Fonts (Morard, 2004). The absence of ammonite characteristic of the lower part of the tenuicostatum Zone at Roqueredonde indicates an important hiatus across the Pl-To transition. This hiatus, reported in numerous sites of the Grands Causses Basin where most of the tenuicostatum Zone is also missing (Trümpy, 1983; Guex et al., 2001; Morard et al., 
2003), has been previously attributed to a short-lived episode of subaerial exposure (Trümpy, 1983; Morard et al., 2003; Mailliot et al., 2009).
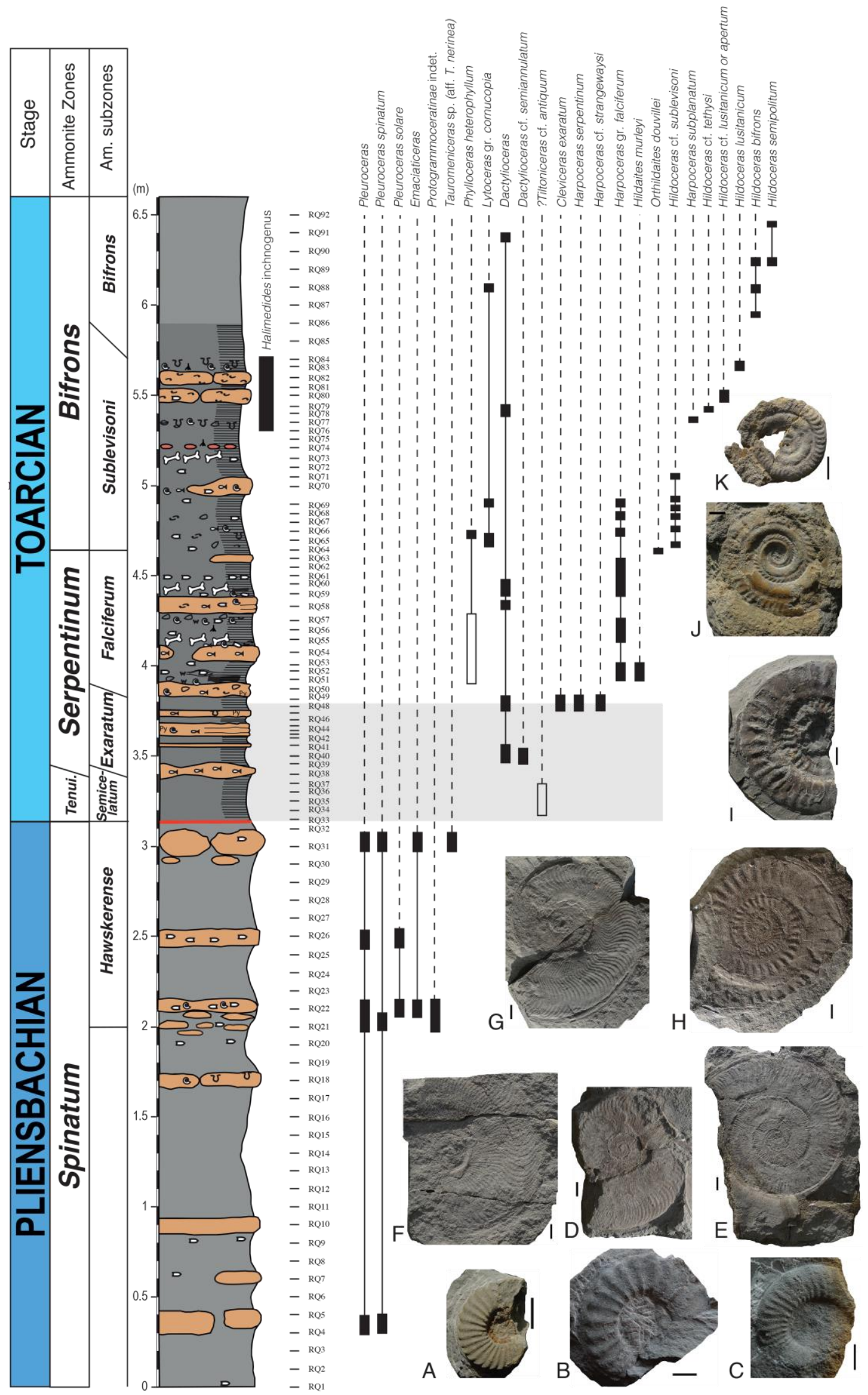
Figure 3: Ammonite biostratigraphy of the Roqueredonde section. A. Pleuroceras solare, RQ26. B. Pleuroceras spinatum, RQ21. C. Tauromeniceras sp. (aff. nerinea), RQ31. D. Harpoceras cf. strangewaysi, RQ48. E. Harpoceras serpentinum, RQ48. F. Cleviceras exaratum, RQ48. G. Harpoceras gr. falciferum, just below RQ64. H. Orthildaites douvillei, RQ64. I. Hildoceras cf. sublevisoni, RQ69. J. Hildoceras bifrons, RQ88. K. Hildoceras semipolitum, between RQ89 and RQ90. Black rectangles - exact position of the taxon; white rectangles - position within the range delimited by rectangle.

The serpentinum Zone occurs from 3.45 to $4.7 \mathrm{~m}$, and includes the exaratum $(3.45$ - 3.85 m) and the falciferum (3.9 - 4.7 m) Subzones (Fig. 3). The index species Harpoceras falciferum is taken here sensu Howarth (1992) who consider the species $H$. pseudoserpentinum and $H$. falciferum as being conspecific. Due to the, mostly in 2D, preservation it is impossible to evaluate decisive morphological patterns for the separation of these species (e.g. character of lateral spiral groove and umbilical wall). Finally, the middle Toarcian bifrons Zone is observed from 4.7 toward the top, including the sublevisoni $(4.7-5.7 \mathrm{~m})$ and the bifrons $(6-6.6 \mathrm{~m})$ Subzones (Fig. 3).

\section{Marine vertebrate remains}

Ichthyosaur vertebrae have been previously found at Roqueredonde, leading to the discovery of a partial ichthyosaur skeleton by the Groupe Archéologique Lodévois and the Museum of Lodève (Hérault, France), in a concretionary limestone detached from the hillside. Determining its exact position within the studied succession deserves further stable-isotope investigation of its associated sedimentary matrix. This specimen, mostly in anatomical connexion and bearing extensive soft tissue preservation. The four field campaigns achieved by our team from 2017 to 2020 revealed the occurrence of three fossiliferous horizons with marine vertebrate remains at $4.15 \mathrm{~m}$ (RQ-55), at $4.4 \mathrm{~m}$ (RQ-59) and at $5.15 \mathrm{~m}$ (RQ 73) (Fig. 2). These campaigns notably exposed a larger, mostly disarticulated and partial ichthyosaur skeleton at $4.15 \mathrm{~m}$ (exhibited at the Museum of Lodève), a small partial marine crocodile specimen in partial anatomical connection at $4.4 \mathrm{~m}$, and a four metres-long longirostrine marine crocodile specimen mostly preserved in anatomical connection at $5.15 \mathrm{~m}$. This material is currently under preparation and investigation at the University of Lyon. All the material was assigned 
and grouped in the inventory number 2020.1 and will be deposited at the Museum of Lodève.

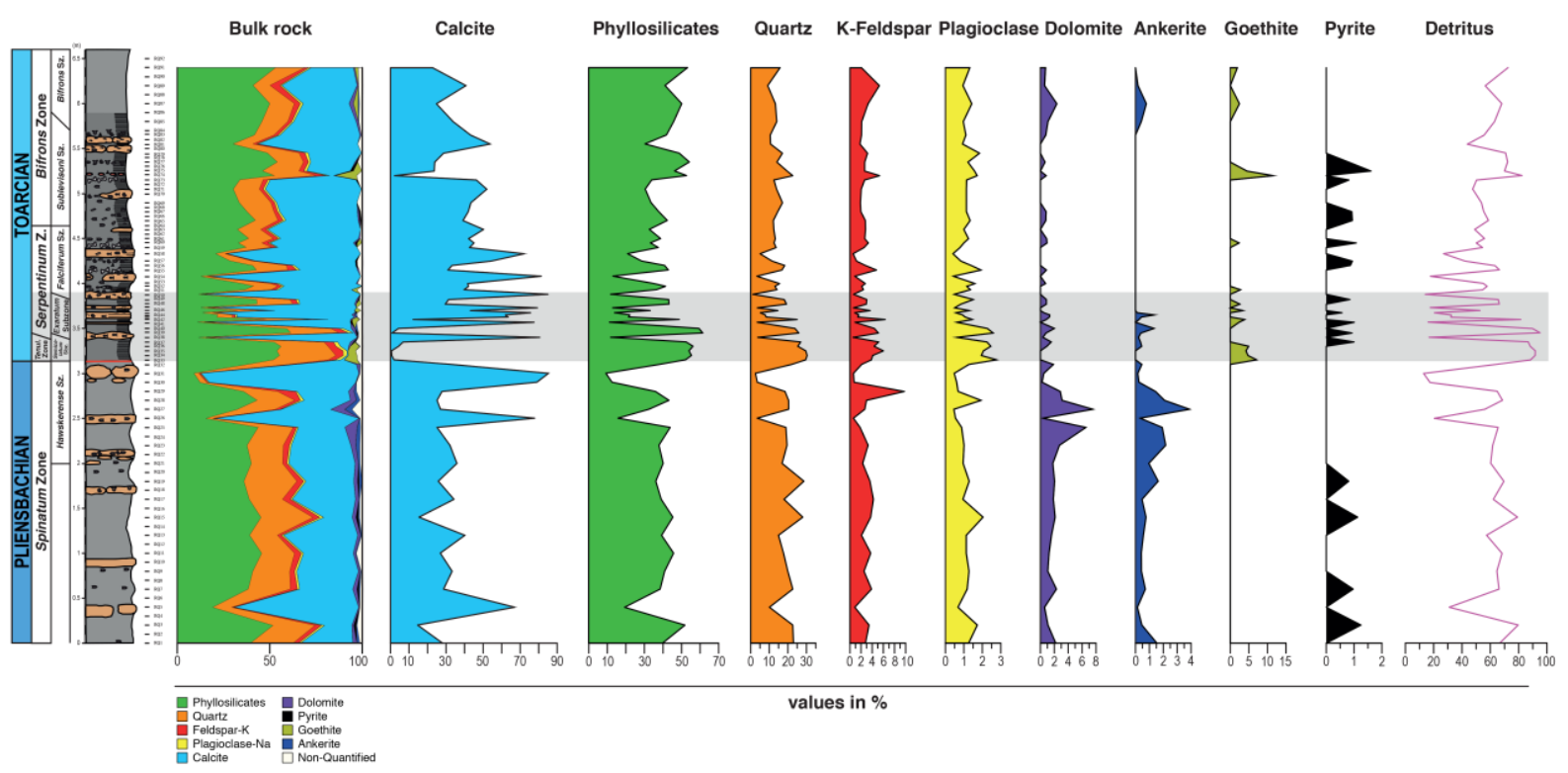

Figure 4: Bulk-rock mineralogy of the Roqueredonde section based on XRD. Mineral phases are expressed in relative percent. The detritus curve is the sum of phyllosilicates, quartz, Kfespar and plagioclase.

\section{Mineralogy}

Bulk rock mineralogical analyses show a dominance of calcite, phyllosilicates and quartz (Fig. 4). K-feldspar, plagioclase and secondary minerals like dolomite, ankerite, goethite and pyrite are also present in lower quantities. In the Pliensbachian interval $(0$ $-3.1 \mathrm{~m})$, the detrital fraction is dominant in the marl beds with phyllosilicates $(\sim 40 \%)$, quartz ( $20 \%)$, and K-felspar ( $\sim 4 \%)$, compared to calcite contents ( $30 \%)$. Conversely, calcite contents fluctuate between 70 to $80 \%$ in the concretionary limestone beds. Dolomite and ankerite contents are higher than in the Toarcian succession and reach a maximum at $2.6 \mathrm{~m}$ ( 8 and $4 \%$ respectively). Goethite is absent in this part, suggesting a differential diagenetic overprint (fluid circulations) linked to the lithological difference between the Marnes de Villeneuves Fm. and the Schistes carton Fm. Calcite contents drop markedly to very low values (0-10\%) in the laminated black shales at the base of the Early Toarcian interval (tenuicostatum Zone) and increase gradually to $40 \%$ until 5 $\mathrm{m}$, alternating with calcite-rich limestone beds ( 80\%). At $5.2 \mathrm{~m}$, an oxidised concretionary bed (RQ-74) is observed with high contents in phyllosilicates, quartz and goethite, and low calcite content. Calcite contents fluctuate between $30-40 \%$, 
phyllosilicates between $40-50 \%$ and quartz between $15-20 \%$ toward the top of the measured section in the Marnes de Fontaneilles Fm. The detritus curve (i.e. the sum phyllosilicates, quartz, K-felspar and plagioclase contents) shows a maximum (more than $80 \%$ ) during the tenuicostatum Zone and the base of exaratum Subzone (Fig. 4).

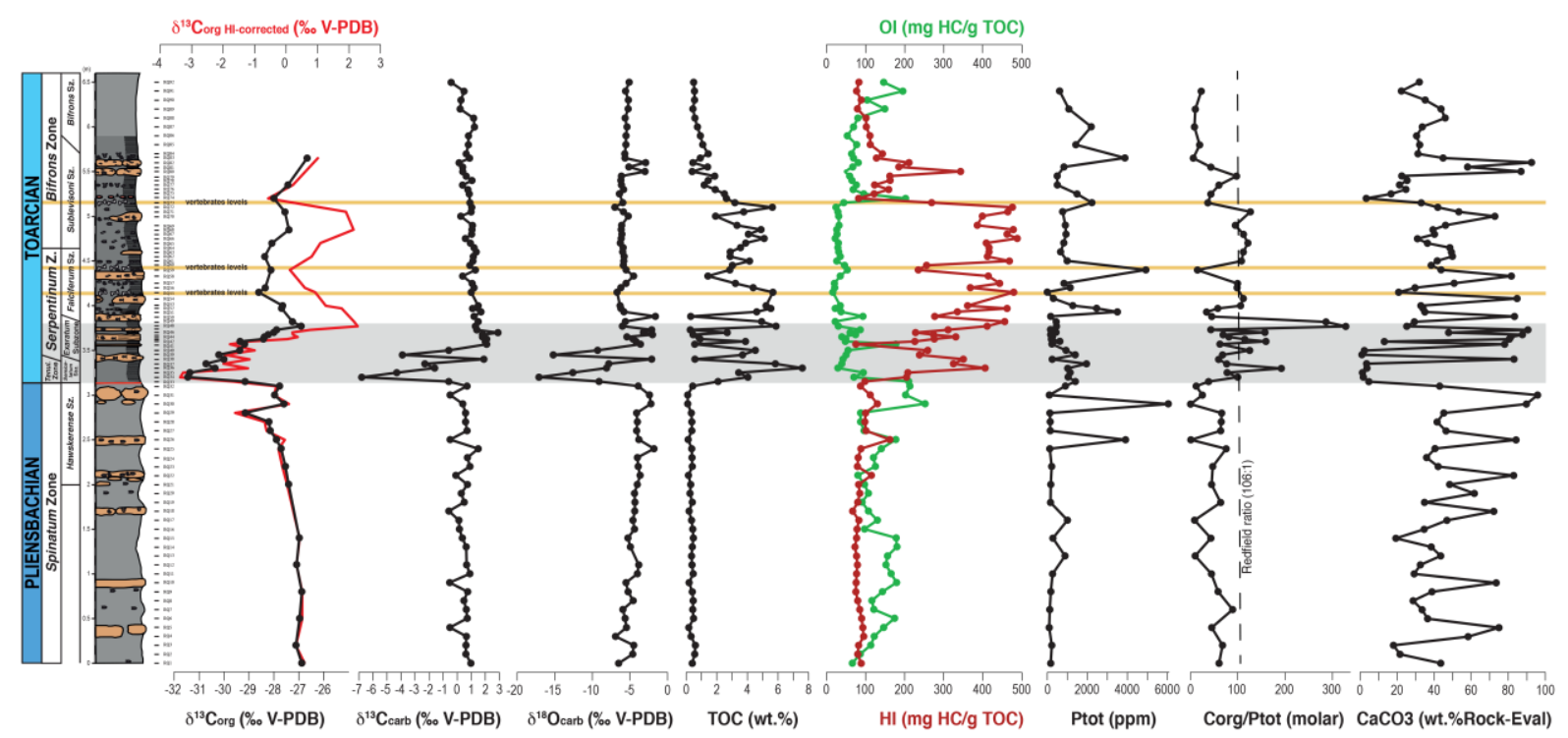

Figure 5: Carbon-isotopes data from bulk organic matter $\left(\delta^{13} \mathrm{C}_{\mathrm{org}}\right)$, organic matter HI corrected $\left(\delta^{13} \mathrm{C}_{\text {orgHIcorrected }}\right)$, and carbonate $\left(\delta^{13} \mathrm{C}_{\text {carb }}\right)$, oxygen-isotope data from bulk carbonate $\left(\delta^{18} \mathrm{O}\right)$, total organic carbon (TOC), hydrogen index $(\mathrm{HI})$, oxygen index (OI), total phosphorus (Ptot), Redfield ratio (Corg/Ptot), and $\mathrm{CaCO}_{3}$ curve based on Rock Eval carbon mineral data, for the Pliensbachian-Toarcian interval at Roqueredonde.

\section{Bulk organic and carbonate stable isotopes}

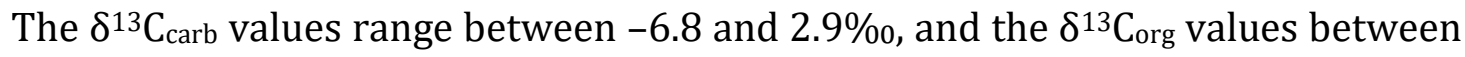
-31.5 and $-26.7 \%$. A sharp decrease in carbonate and organic carbon isotopes is observed at the Pl-To boundary ( -31.5 and $-6.8 \%$ respectively) followed by a gradual increase in the $\delta^{13} C_{\text {org }}$ values and a more scattered increase in $\delta^{13} C_{\text {carb }}$ values in the exaratum Subzone (Fig. 5). Both bulk organic and carbonate thus record a characteristic negative CIE across the tenuicostatum Zone and the exaratum Subzone that is here correlated to that typically associated with the CIE marking the onset of the T-OAE. The $\delta^{13} \mathrm{C}_{\text {carb }}$ and $\delta^{13} \mathrm{C}_{\mathrm{org}}$ are slightly decoupled toward the upper part of the negative CIE at Roqueredonde, with the more scattered $\delta^{13} C_{\text {carb }}$ values reaching maximum values $20 \mathrm{~cm}$ below the $\delta^{13} C_{\text {org }}$ values (Fig. 5).

The bulk carbonate $\delta^{18} 0$ values are very low and range from -17.1 to $-1.8 \%$, especially during the tenuicostatum Zone (interval quite enriched in goethite). 


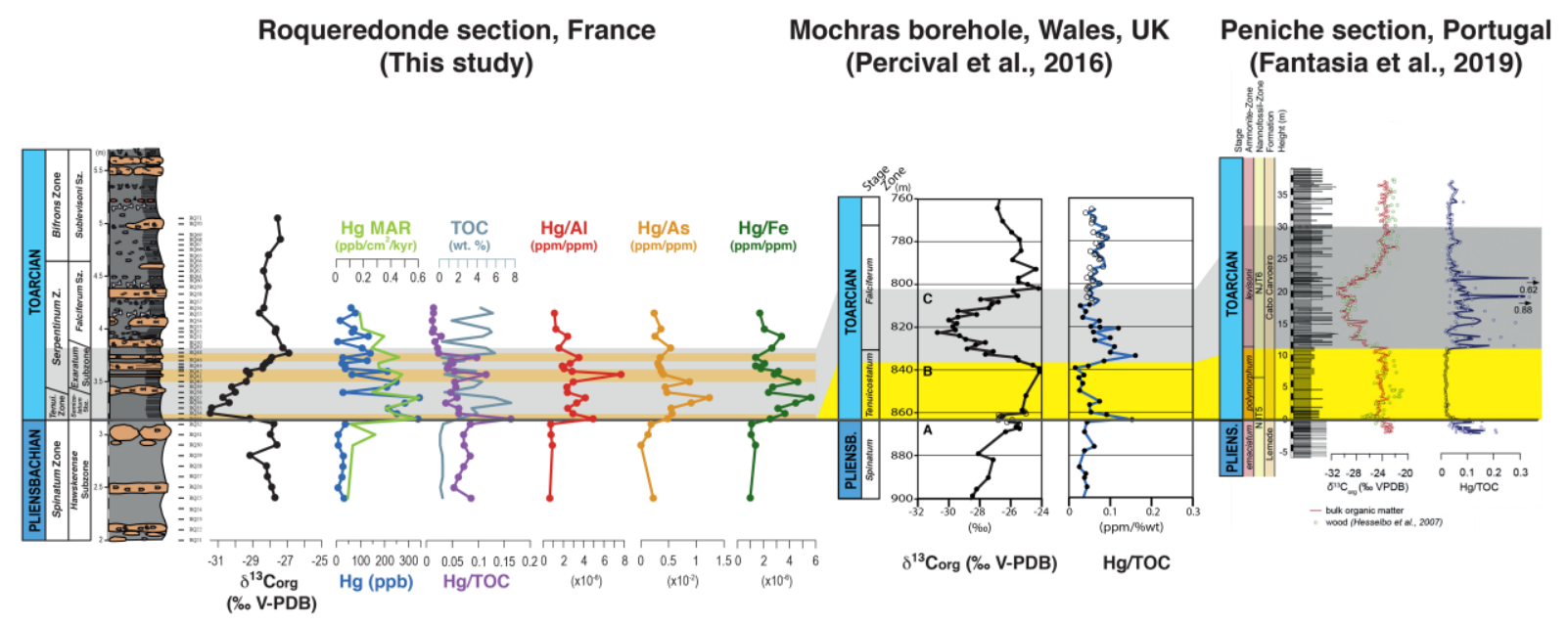

Figure 6: Comparison of $\mathrm{Hg}, \mathrm{Hg}$ MAR (mass accumulation rate) and $\mathrm{Hg} / \mathrm{TOC}$ data of the Roqueredonde section with those from Percival et al., 2016 (Mochras borehole, UK) and Fantasia et al., 2019 (Peniche, Portugal). Hg normalisation curves on Al, As and Fe show substantial $\mathrm{Hg}$ enrichment in the negative CIE interval.

\section{Phosphorus content}

Total phosphorus (Ptot) contents range from 2 to $6045 \mathrm{ppm}$ throughout the section (Fig. 5). The Ptot contents are relatively low and fluctuate between 100 and 280 ppm during the Pliensbachian interval. Some distinct peaks in Ptot occur at 1.2 and 1.3 m (Fig. 5; RQ-13 and 17). Peaks in Ptot ranging between 900 to 6000 ppm also occur in the Schistes carton Fm. at 2.5 and 2.9 m (Fig. 5; RQ-26 and 30) and correspond to limestone beds enriched in fish debris. The Ptot contents increase to values of $2000 \mathrm{ppm}$ during the negative CIE interval at $3.35 \mathrm{~m}$ (RQ-37) and decrease up to its termination at $3.88 \mathrm{~m}$ (RQ-50). After the negative CIE interval, Ptot contents fluctuate between 300 and 1200 ppm, alternating with strong peak ranging between 2200 to 4900 ppm at RQ-51, 59, -73, -83 and -87 (Fig. 5).

The Corg/Ptot ratio is relatively low throughout the section, fluctuating between 0 and 100 , but reaches a maximum value of 430 at $3.77 \mathrm{~m}$ (RQ-48) during the negative CIE interval (Fig. 5). The Corg/Ptot ratios are higher than the Redfield ratio (106:1; Redfield, 1958) in the negative CIE interval and in two intervals in the falciferum and the sublevisioni Subzones (Fig. 5). 
Total organic carbon (TOC) content are very low $(<1 \mathrm{wt} \%)$ in the Pliensbachian interval and increase sharply across the Pl-To transition, with a maximum value of 7.6 wt\% recorded at $3.3 \mathrm{~m}$ (RQ-36; Fig. 5). The TOC values remain quite high in the Schistes carton Fm., where they fluctuate markedly in relationship with calcite contents, and decrease gradually from $5.1 \mathrm{~m}$ (RQ-72) up to the top of the section (Fig. 5). The Pliensbachian interval is characterised by relative low HI (mean value of $90 \mathrm{mg} \mathrm{HC} \mathrm{g}{ }^{-1}$ TOC) and moderate OI values (mean value of $137 \mathrm{mg} \mathrm{CO}_{2} \mathrm{~g}^{-1} \mathrm{TOC}$ ). The Pl-To boundary records a sharp increase in $\mathrm{HI}$ and decrease in $\mathrm{OI}$, coeval with the sharp increase in TOC (Fig. 5). HI values reach maximum values of 400-500 $\mathrm{mg} \mathrm{HC} \mathrm{g}^{-1} \mathrm{TOC}$ above the negative CIE between 3.7 and $5.1 \mathrm{~m}$ (RQ-72; Fig. 5), where minimum OI values occur $(<50 \mathrm{mg} \mathrm{CO} 2$ $\mathrm{g}^{-1}$ TOC). A sharp decrease in HI and increase in OI values occur above $5.1 \mathrm{~m}$ (Fig. 5), followed by a moderate peak in HI at $5.5 \mathrm{~m}$ (RQ-80; Fig. 5).

\section{Mercury content}

Mercury (Hg) contents are very low in the Pliensbachian interval, ranging between 7 and 36 ppb (Fig. 6). At the Pl-To boundary, Hg contents sharply increased to a value of $338 \mathrm{ppb}$ and decrease gradually throughout the negative CIE interval to lower values (Fig. 6). Hg values were normalised by TOC to remove the effect of organic matter due to high affinity of Hg to organic carbon (e.g. Grasby et al., 2013; Percival et al., 2015). After normalisation, some significant peaks in $\mathrm{Hg}$ /TOC ratios still remain through the TOAE interval and are consistent with those observed in the same interval in different localities (Fig. 6; Percival et al., 2016; Fantasia et al., 2019).

\section{Major and trace elements}

The most abundant major elements are $\mathrm{SiO}_{2}(4-50 \%)$ and $\mathrm{CaO}(0-49 \%)$, followed by $\mathrm{Fe}_{2} \mathrm{O}_{3}(0.8-19 \%), \mathrm{Al}_{2} \mathrm{O}_{3}(1.5-17 \%), \mathrm{K}_{2} \mathrm{O}(0.3-4.9 \%)$ and $\mathrm{MgO}(0.7-3 \%)$ (Fig. 7). $\mathrm{TiO}_{2}$, $\mathrm{MnO}, \mathrm{NiO}$, and $\mathrm{Na}_{2} \mathrm{O}$ contents are $\leq 1 \%$ (Fig. 7). Most of these elements, in particular $\mathrm{SiO}_{2}, \mathrm{Al}_{2} \mathrm{O}_{3}, \mathrm{~K}_{2} \mathrm{O}$ and $\mathrm{TiO}_{2}$, follow the same trends as the detritus curve (Fig. 4). The upper part of the Pliensbachian interval is marked by a decreasing trend of these elements, just before a strong increase during the first part of the negative CIE interval, followed by a gradual decrease until the end of the exaratum Subzone (Fig. 7). 
Major elements

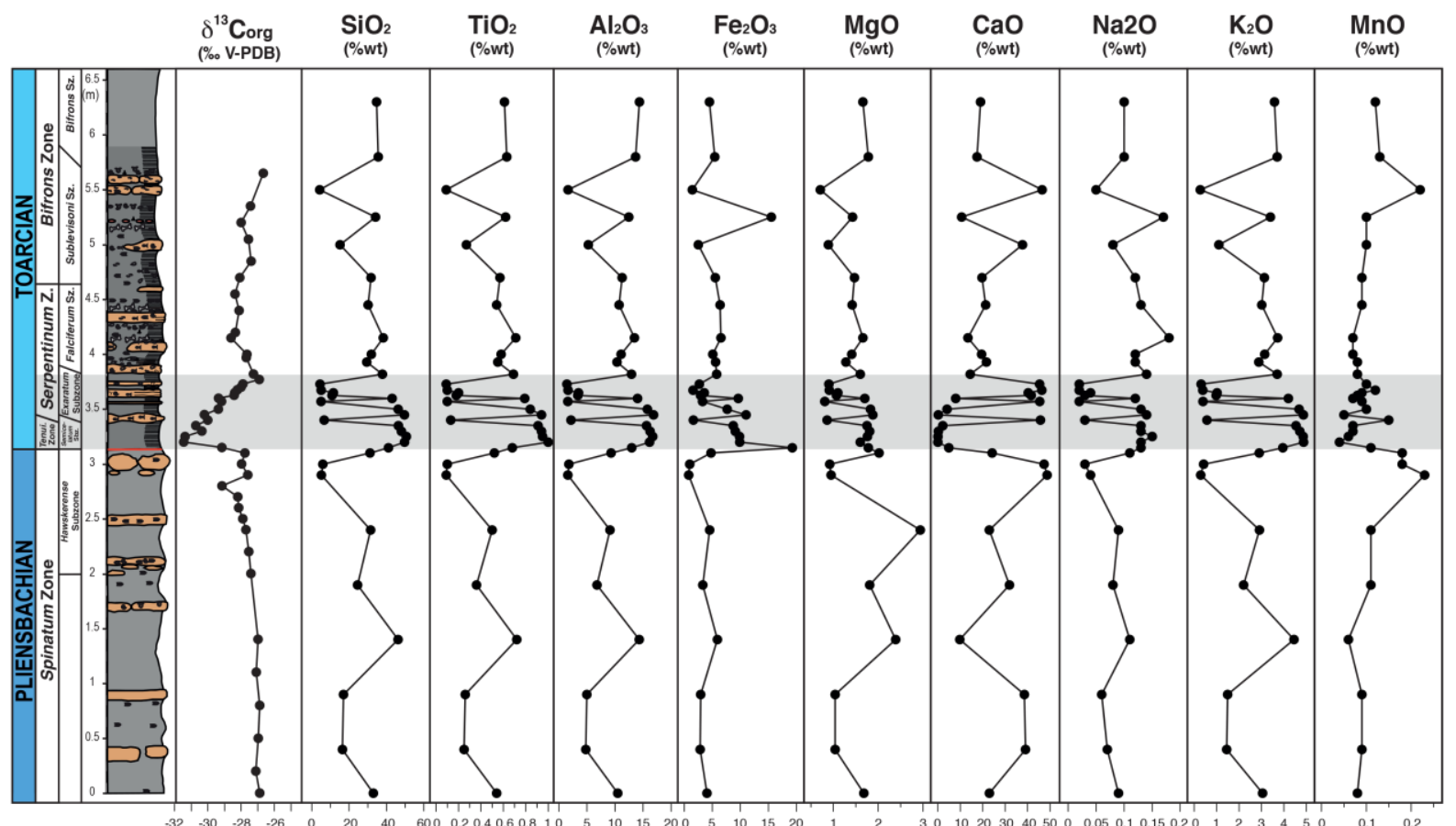

Trace elements

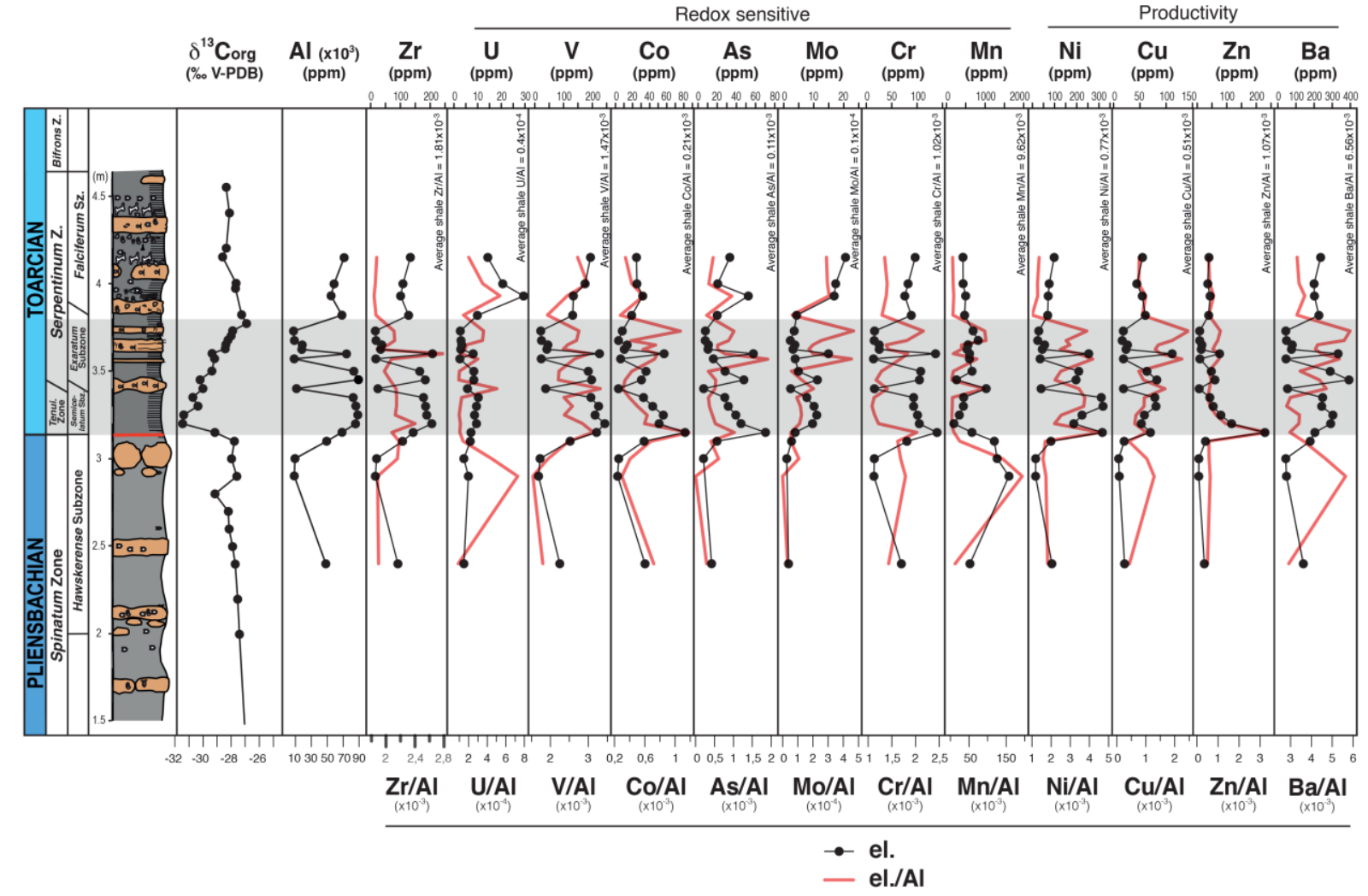

Figure 7: Major-element contents (wt\%), trace-element contents (in ppm; in dark line) and Al-normalised contents (in red line). Average shale values are from Wedepohl (1971). 
Above, these trace elements increase again to higher values, which persist from the base of the falciferum Subzone up to the top of the section, only interrupted at $5.5 \mathrm{~m}$ by lower values (Fig. 7). The exceptions are $\mathrm{CaO}$ and $\mathrm{MnO}$, which inversely mirror these elements linked to detrital inputs. The $\mathrm{Fe}_{2} \mathrm{O}_{3}$ contents show no clear correlation with others elements, but exhibit similar trends to the goethite contents (Fig. 4). A significant increase in $\mathrm{MgO}$ is observed at $2.4 \mathrm{~m}$ (RQ-25; Fig. 7) and corresponds to high content in dolomite (Fig. 4).

The investigation of trace-element behaviour was focused on the interval located between 2.4 and $4.15 \mathrm{~m}$, which comprises the negative CIE interval (Fig. 7). Different trends in trace-element concentrations are observed (Fig. 7). Most of them follow the same trends depicted by $\mathrm{Al}$ abundance and detritus curves, as $\mathrm{Zr}, \mathrm{V}, \mathrm{Cr}$ and $\mathrm{Ba}$ which are strongly correlated with $\mathrm{Al}\left(\mathrm{R}^{2} \geq 0.9\right)$; and $\mathrm{Cu}, \mathrm{Ni}$ and $\mathrm{Co}$ which also show an excellent linear correlation with $\mathrm{Al}\left(\mathrm{R}^{2} \geq 0.8\right)$, suggesting a siliciclastic origin. Only $\mathrm{Zn}, \mathrm{Mn}$, Mo $\left(R^{2} \leq 0.6\right)$ and $U\left(R^{2}<0.4\right)$ show a weaker relationship with Al. Throughout the section, the detrital fraction exceeds $5 \%$ and the coefficient of variation of $\mathrm{Al}$ content is lower or of the same order than most trace-elements (See supplementary data). Al-normalisation can therefore reasonably be used to estimates the degree of enrichment of these sensitive elements (e.g. Riquier et al., 2006). Al-normalised $\mathrm{U}, \mathrm{Co}, \mathrm{Mo}, \mathrm{Cr}, \mathrm{Cu}$ and $\mathrm{Ba}$ contents exhibit an increasing trend toward the top of the negative CIE interval, with a maximum in the 3.6-3.8 $\mathrm{m}$ interval. In contrast, $\mathrm{Mn}, \mathrm{Zn}$ and $\mathrm{V}$ values strongly decrease in the negative CIE interval.

\section{Discussion}

Stable isotope- and bio-stratigraphy and diagenesis

The $\delta^{13} \mathrm{C}$ record at Roqueredonde is broadly comparable to existing lower Toarcian $\delta^{13} \mathrm{C}$ records from other sites (e.g., Jenkyns and Clayton, 1986, 1997; Schouten et al., 2000; Hesselbo et al., 2007; Suan et al., 2011; Fantasia et al., 2018b; Remírez and Algeo, 2020b). A notable feature is the absence of negative CIE across the Pl-To boundary and the following positive shift in $\delta^{13} \mathrm{C}$ documented in many sites, supporting the hypothesis of a prolonged episode of erosion or non-deposition also suggested by ammonite biostratigraphy (Fig. 5). Our biostratigraphic and chemostratigraphic records show that the Roqueredonde section has a much-reduced thickness compared to adjacent, more basinal sections of the Grand Causses Basin, where a hiatus at the Pl-To 
boundary (missing part of tenuicostatum Zone) has been also suggested by $\delta^{13} \mathrm{C}$ - and bio-stratigraphy. The identification of $>30 \mathrm{~m}$ incised valleys filled by sediments recording the negative CIE in Morocco and Greenland indicate that this hiatus is supraregional and maybe glacio-eustatic in origin (Krencker et al., 2019).

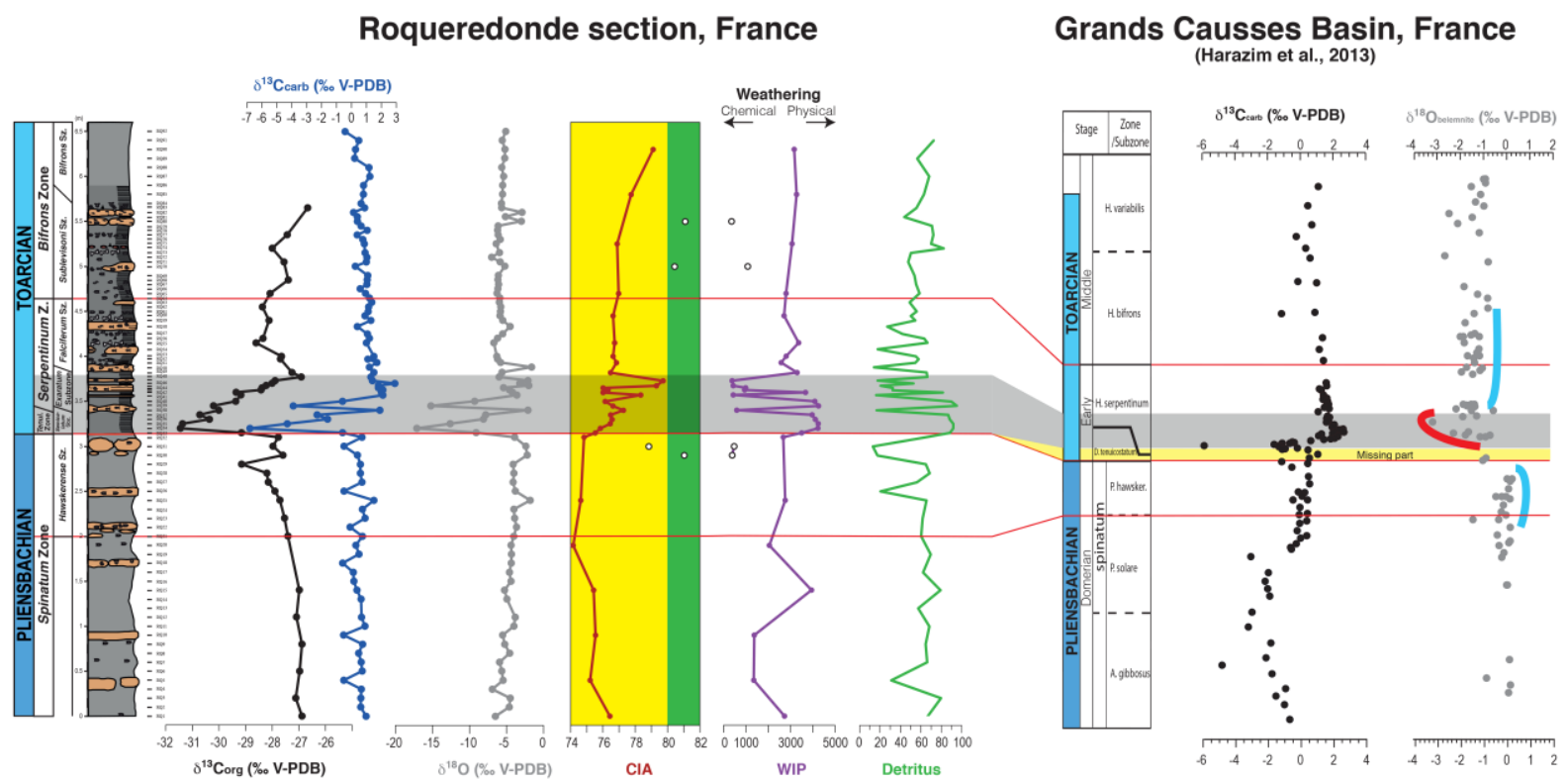

Figure 8: Comparison of carbon $\left(\delta^{13} \mathrm{C}_{\text {org }}\right.$ and $\left.\delta^{13} \mathrm{C}_{\mathrm{carb}}\right)$ and oxygen isotopes, chemical index of alteration (CIA), weathering index of Parker (WIP) and detritus curve with carbon and oxygen isotopes from the Grands Causses Basin (Harazim et al., 2013). White dots in the CIA and WIP curves indicate diagenetic limestone levels.

As previously documented in the Tournadous and Saint-Paul-des-Fonts sections located a few km North of Roqueredonde (Mailliot et al., 2009), the limestone beds and concretions present in our profile values systematically record lower $\delta^{13} \mathrm{C}_{\text {carb }}$ values than adjacent lithologies (Fig. 5), suggesting a higher contribution of organic matterderived carbonates. The very low bulk carbonate $\delta^{18} \mathrm{O}$ values (down to $-17.1 \%$ ) in the tenuicostatum Zone suggest either a strong freshwater input during deposition or later diagenetic overprint due to meteoric pore-water circulation. The moderate positive linear correlation observed between $\delta^{13} \mathrm{C}_{\text {carb }}$ and $\delta^{18} \mathrm{O}$ values $\left(\mathrm{R}^{2}=0.53\right)$ may suggest a secondary influence on $\delta^{13} \mathrm{C}_{\text {carb }}$ values, which record a negative CIE with a magnitude ($7 \%$ ) much larger than that $(-4 \% 0)$ recorded in coeval sites of the Northwest European Shelf (NWES) (Remírez and Algeo, 2020b).

Likewise, the changes in Rock-Eval pyrolysis parameters at Roqueredonde indicate marked change in the dominant kerogen type that likely impacted $\delta^{13} \mathrm{C}_{\text {org }}$ signal. 
The high HI values recorded between 3.15 and $5.2 \mathrm{~m}$ indicate a dominance of hydrogenrich kerogen of type II (algal/bacterial), while lower HI values in older and younger intervals indicate the dominance of kerogen of type III-IV (terrestrial/strongly oxidised kerogen). Previous studies of NW European lower Toarcian sites have shown that these kerogen types have distinct $\delta^{13} C_{\text {org }}$ signatures, with type II organic matter being depleted in ${ }^{13} \mathrm{C}$ by about 3 to $4 \%$ o relative to type III/IV kerogen (Suan et al., 2015). The $\mathrm{HI}$ and $\delta^{13} \mathrm{C}_{\text {org }}$ values show no correlation at the studied site $\left(\mathrm{R}^{2}=0.03\right)$, suggesting that changing kerogen type exerted a secondary influence on $\delta^{13} \mathrm{C}_{\text {org }}$ values. We have tentatively corrected the $\delta^{13}$ Corg profile for changing kerogen type applying the procedures described by Suan et al. (2015). We used a slope (a) of 0.0053 taken from their HI- $\delta^{13}$ Corg relationship outside the T-OAE in SW German sites and an intercept (b) of $-27 \%$ based on the lower background (Pliensbachian) $\delta^{13} \mathrm{C}_{\text {org }}$ values recorded at Roqueredonde compared to SW German sites (-26\%). The obtained $\delta^{13} \mathrm{CHI}_{\mathrm{H}}$ corrected profile records a larger shift toward higher $\delta^{13} \mathrm{C}$ values above the negative CIE between 3.8 and $5 \mathrm{~m}$ (Fig. 5) and is hence more similar to the $\delta^{13} \mathrm{C}_{\text {bulk carb signal than the original }}$ $\delta^{13}$ Corg profile. These comparisons suggest that differential organic matter preservation along the section has slightly overprinted the $\delta^{13} \mathrm{C}_{\text {org }}$ profile, particularly in the interval recording highest $\mathrm{HI}$ values above the negative CIE.

Notwithstanding the lower tenuicostatum Zone hiatus and local and diagenetic overprints, the organic and inorganic $\delta^{13} \mathrm{C}$ profiles at Roqueredonde are comparable with numerous Toarcian records worldwide, allowing high-resolution correlations and the establishment of a detailed temporal framework (Fig. 6). Our new $\delta^{13} \mathrm{C}$ record notably show that the "Leptolepis bed", a conspicuous marker bed observed at the base of the serpentinum Zone in the whole Grand Causses basin (Trümpy, 1983; Morard et al., 2003) formed synchronously with comparable concretionary limestone beds such as that the "whale stones" in UK (Kemp et al., 2005), "Unterer Stein"in SW Germany (Röhl et al., 2001) and an unnamed bed in Siberia (Suan et al., 2011). Previous studies suggested that the widespread formation of such concretionary limestone beds at the termination of the negative CIE could have been promoted by a sudden rise of alkalinity due to higher organic matter fluxes (Sun and Turchyn, 2014; Brazier et al., 2015). A recent geochemical study of the "Unterer Stein" in SW Germany suggested that its formation may have been fostered by a bloom of green sulphur bacteria, which caused a sudden deepening of the base of the chemocline near the sediment-water interface, 
hence increasing sulphate and Mn fluxes and eventually carbon remineralisation by sulphate-reducing bacteria (Wang et al., 2020).

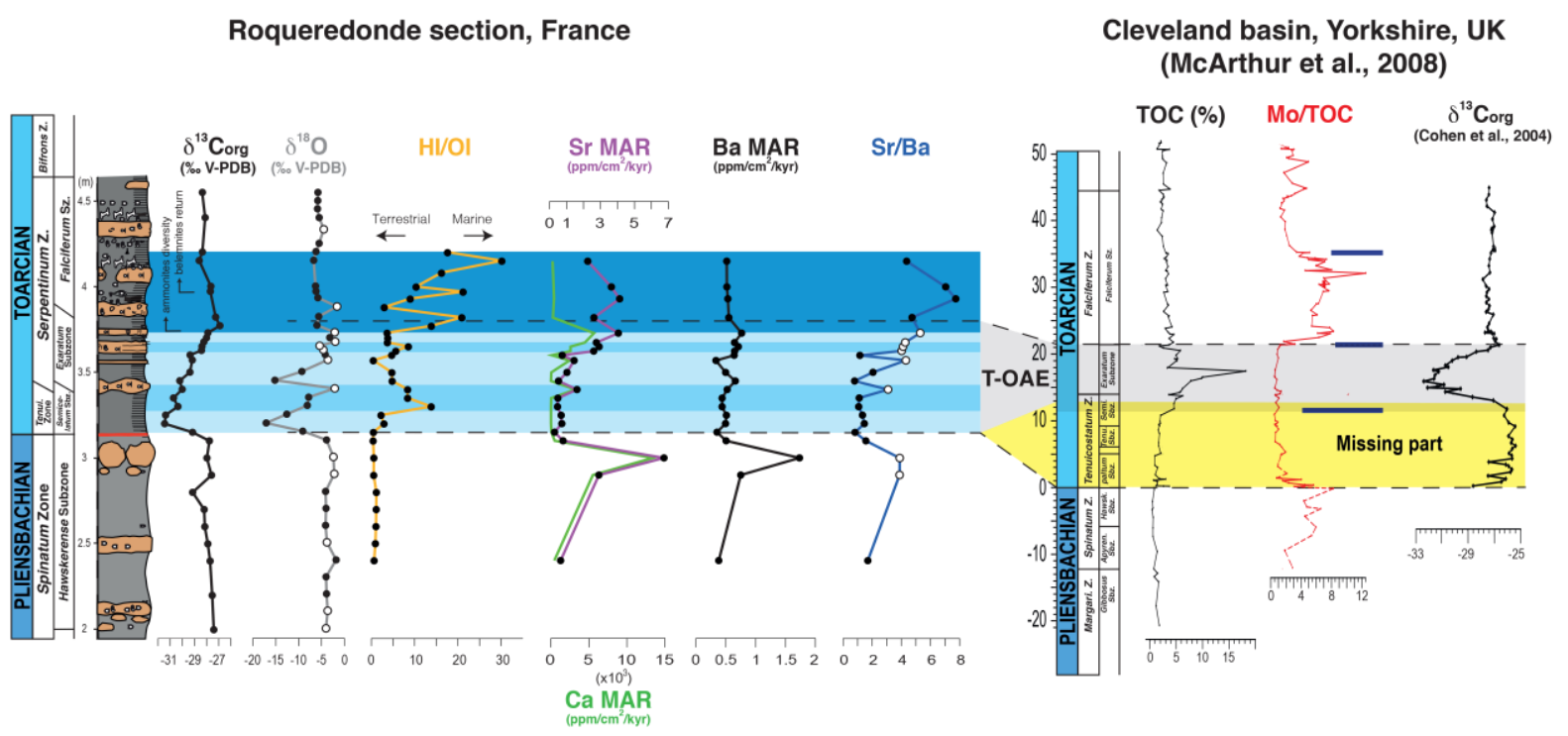

Figure 9: Hydrogen and Oxygen indices ratio (HI/OI), indicating organic matter origins, $\mathrm{Sr}$, $\mathrm{Ba}, \mathrm{Ca}$ trace elements in MAR (mass accumulation rate), paleosalinity proxy $\mathrm{Sr} / \mathrm{Ba}$ data from the Roqueredonde section compared to paleosalinity proxy Mo/TOC from the Cleveland Basin, UK (McArthur et al., 2008). Intensity of blue shades indicate the qualitative intensity of salinity (Dark blue: marine influences; light blue: fresh water influences)

\section{Reconstruction of mass accumulation rates}

The interpretation of changes in sedimentary components in the Roqueredonde section, as in many black-shale bearing sites of the same age, is complicated by the occurrence of several limestone beds that evidently record a much shorter time span than adjacent clay-rich lithologies. First, fossils (i.e., ammonites, bivalves and vertebrate bones) found in limestone beds are much less flattened than those found in shale beds, pointing to lower burial compaction and earlier cementation of porewater space than in shale beds, as shown for coeval SW German sites (Martill, 1993). Second, CaCO3-rich beds of the Schistes carton Fm systematically show lower TOC and RSTE contents than $\mathrm{CaCO}_{3}$-poor adjacent beds, whereas both lithologies show similar HI values (Fig. 5). The HI values indicate comparable proportions of oxidation-prone hydrocarbons in organic matter, strongly suggesting that lower TOC and RSTE contents in $\mathrm{CaCO}_{3}$-rich beds result from higher dilution by carbonate minerals rather than higher aerobic degradation.

To overcome this dilution/compaction issue, we have reconstructed accumulation rates of each component recorded in the new (Roqueredonde) and 
published records of the Grands Causses Basin (Tournadous and Saint-Paul-des-Fonts; Morard, 2004; Mailliot et al., 2009) assuming a constant input of the detrital fraction as a working hypothesis. The sedimentation rate was first calculated for each level using the following equation:

$\mathrm{SR}=\mathrm{F}_{\text {detrital fraction }} /([$ detrital fraction $] *$ DBD) (1)

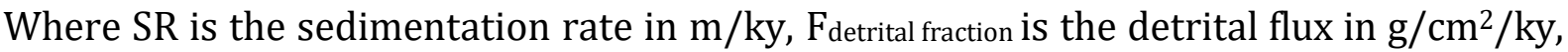
[detrital fraction] is the weight \% concentration of the detrital fraction, here taken as the non-carbonate and non-organic fraction (100-CaCO $3-\mathrm{TOC})$ of the sediment for the sake of simplicity, and DBD the dry bulk density, which, in the absence of measurements, was

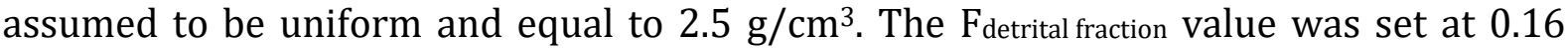
$\mathrm{g} / \mathrm{cm}^{2} / \mathrm{ky}$ in Roqueredonde to obtain a total duration of $600 \mathrm{kyr}$ for the negative CIE, in line with the shortest astronomical age models (Boulila and Hinnov, 2017). Taking account longer estimates for this interval (Ruebsam and Al-Husseini, 2020; Suan et al.,

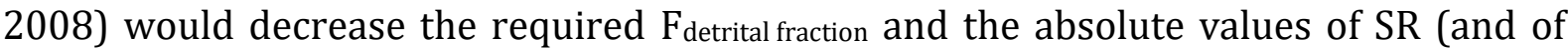
reconstructed sedimentary component fluxes), but would not alter their relative changes.

The Fdetrital fraction value was then estimated at Tournadous and Saint-Paul-des-Fonts to obtain the best match between their published geochemical $\left(\delta^{13} \mathrm{C}_{\mathrm{carb}}, \delta^{18} \mathrm{O}, \mathrm{CaCO}_{3}, \mathrm{TOC}\right)$, lithostratigraphic and biostratigraphic data (Morard, 2003; Mailliot et al., 2009; Pinard et al., 2014) and those presented here for Roqueredonde. The resulting $F_{\text {detrital fraction }}$ are given in Table 1. In each section, the time comprised between two successive samples was determined by dividing the difference between their stratigraphic heights divided by the average SR of the two samples. The obtained age models are expressed relative to the base of the Schistes carton Fm. A duration of $\sim 600$ ky was assumed for the hiatus between the uppermost Pliensbachian and lowermost Toarcian samples (Fig. 11), following the estimate of Ruebsam et al. (2020; their 'SBH2').

The Mass Accumulation Rate (MAR) of each sedimentary component was then reconstructed by rearranging equation (1) into:

$\operatorname{MARx}=\mathrm{SR}^{*}[\mathrm{X}] * \mathrm{DBD}(2)$

where SR and DBD are identical to equation (1), MARx and [X] are the MAR and weight $\%$ concentration of each considered component X. 

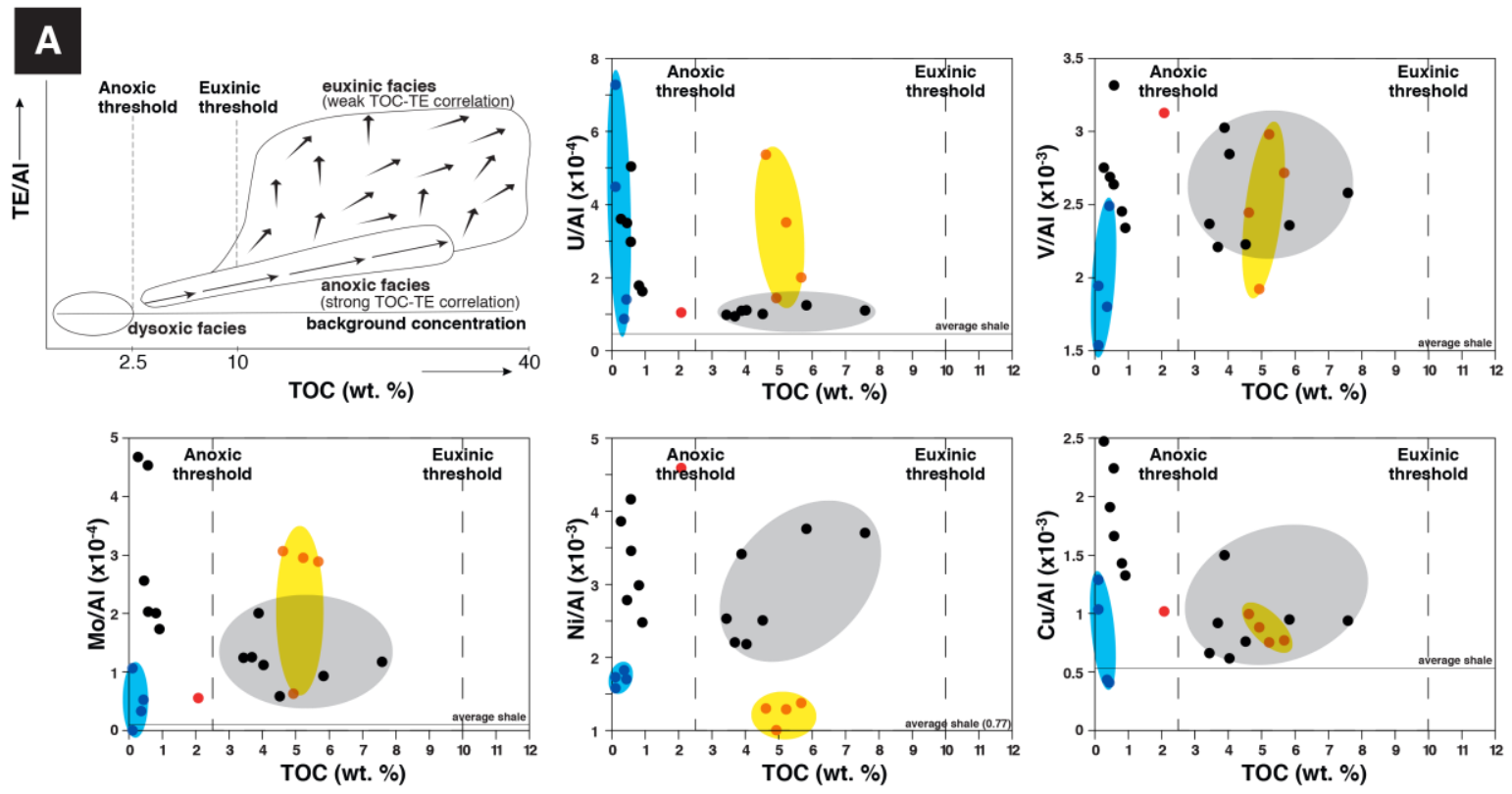

Pliensbachian levels

- T-OAE CIE levels

Post-T-OAE levels

- Red clay layer

\section{B}

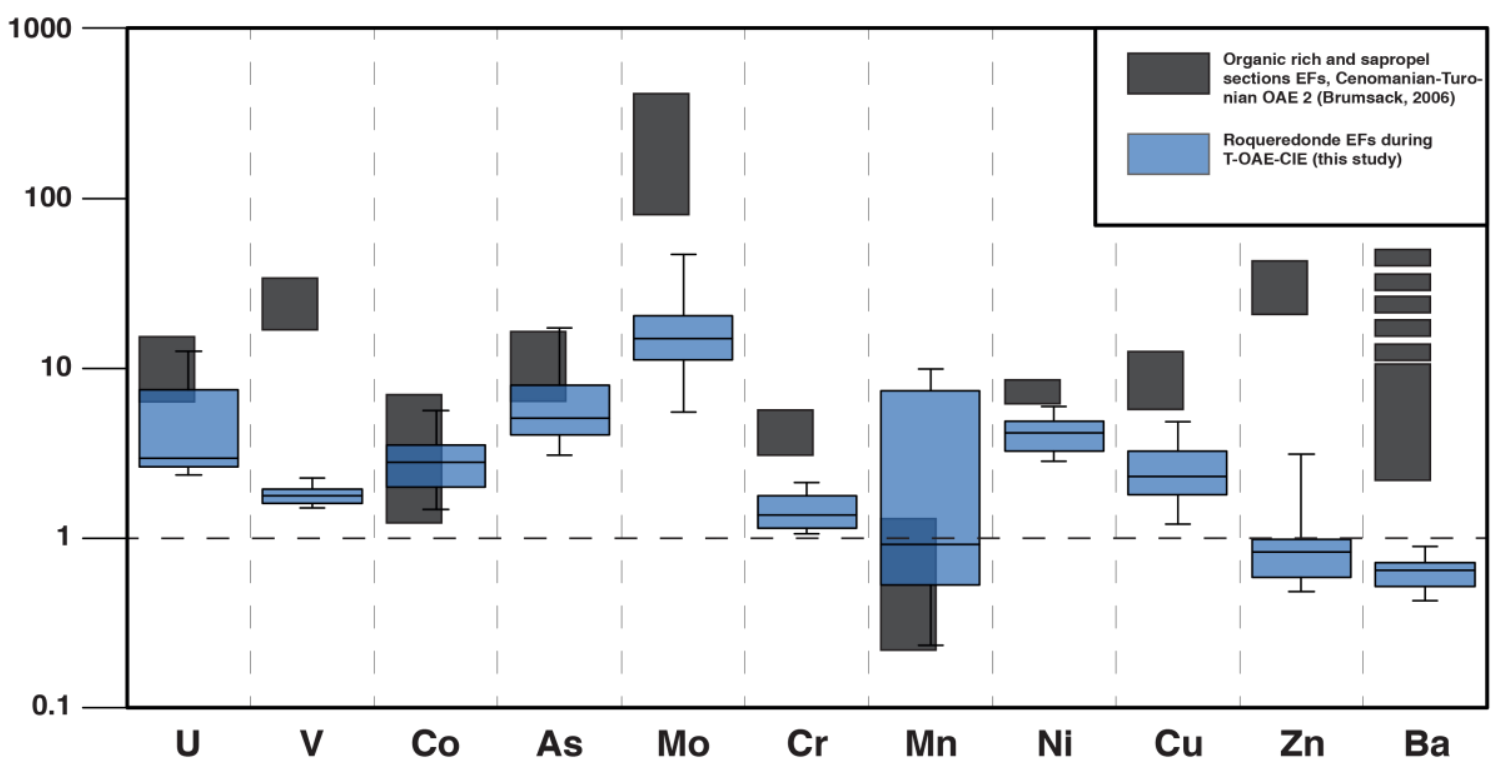

Figure 10: (A) Scatterplots of Al-normalised trace elements and total organic carbon (TOC) content illustrating the redox facies (after Algeo and Maynard, 2004) at Roqueredonde. Blue dots (Pliensbachian interval), black dots (T-OAE CIE interval), orange dots (Post T-OAE interval) and red dot (Pliensbachian-Toarcian red clay layer). Note that black dots outside the grey shade belong to limestones beds. (B) Calculated enrichment factors relative to average shale for trace-element contents measured in the Roqueredonde section. T-OAE CIE interval values (blue box-plot) are compared with organic-rich Cenomanian-Turonian sections (dark grey box-plot) taken from Brumsack (2006). 
We acknowledge that our assumption of a fixed detrital input across the studied interval is certainly invalid given the ample evidence for changes in continental weathering during the T-OAE (Percival et al., 2016). We consider, however, this working hypothesis as a reasonable approach for the deconvolution of primary sedimentary fluxes. Indeed, sensitivity tests show that imposing a doubling of detrital fluxes during the negative CIE have a minor impact on the reconstructed MAR trends compared to the variable dilution by carbonate minerals. The obtained trends in the MAR of some selected sedimentary components are discussed in the sections below.

\section{Karoo-Ferrar volcanism and Hg enrichment}

The $\mathrm{Hg} / \mathrm{TOC}$ anomalies occurring within the T-OAE negative CIE interval at Roqueredonde (highlighted in orange intervals; Fig. 6) are similar to those recorded in other sites in NW and SW European Shelf and NW and SW Panthalassic Ocean (compilation of Remírez and Algeo, 2020b), suggesting a temporal link with the KarooFerrar volcanism (Percival et al., 2015; Fantasia et al., 2018a, 2019). Numerous studies have indeed used $\mathrm{Hg} / \mathrm{TOC}$ ratios recorded into the sediment to trace volcanic activity (Sanei et al., 2012; Sial et al., 2013; Percival et al., 2015; Font et al., 2016; Charbonnier et al., 2017; Fantasia et al., 2018a, 2019; Shen et al., 2019; Grasby et al., 2019). The rationale is that volcanic activity releases gaseous elemental $\mathrm{Hg}$ into the atmosphere, which is then transferred to the sedimentary reservoir by adsorption onto clay particles or organic Hg-complexes (e.g. Grasby et al., 2013). However, recent studies suggested that sedimentary Hg enrichment could also be influenced by changes in detrital fluxes, redox conditions, wildfire activity or recent weathering of organic material (Percival et al., 2015; Them II et al., 2019; Grasby et al., 2019; Charbonnier et al., 2020). Some Toarcian sections (e.g. UK, Canada and Germany) for instance show no clear $\mathrm{Hg}$ enrichment during the T-OAE onset (Percival et al., 2015; Them II et al., 2019), possibly due to high sedimentation rates or low organic matter burial rates (Percival et al., 2015). Following Them II et al. (2019), Hg enrichments in Toarcian records could track changes in terrestrial input and water column redox conditions rather than volcanism.

At Roqueredonde, our new data indicate that all these parameters likely influenced the Hg contents. The Hg contents show: 1) a poor linear positive correlation with RSTEs independent from clastic influx ( $\mathrm{U}: \mathrm{R}^{2}=0.06$; Mo: $\mathrm{R}^{2}=0.12 ; \mathrm{Mn}: \mathrm{R}^{2}=0.28$ ); ) a 
good linear positive correlation with RSTEs dependent on clastic influx (Ni: $\mathrm{R}^{2}=0.92 ; \mathrm{V}$ : $\mathrm{R}^{2}=0.71$; $\mathrm{Cu}: \mathrm{R}^{2}=0.70$ ); and 3) a moderate to good linear positive correlation with other elements linked to clastic input as $\mathrm{Al}\left(\mathrm{R}^{2}=0.67\right)$, $\mathrm{Ti}\left(\mathrm{R}^{2}=0.69\right)$ and $\mathrm{Zr}\left(\mathrm{R}^{2}=0.70\right)$. In this regard, the reconstructed $\mathrm{Hg} \mathrm{MAR}$ and $\mathrm{Hg} / \mathrm{Al}$ ratios still exhibit enrichment in $\mathrm{Hg}$ during the T-OAE CIE, in particular at the Hg/TOC peaks (Fig. 6), suggesting that diminished $\mathrm{CaCO}_{3}$ fluxes exacerbated but not entirely explain the higher $\mathrm{Hg}$ contents. Analyses of a coeval, strongly weathered T-OAE succession from Beaujolais (France) have shown that recent weathering tend to strongly diminish TOC contents without substantially affecting Hg contents (Charbonnier et al., 2020). Recent weathering has clearly affected our samples from the lowermost Toarcian (RQ33-34) that show a diagnostic brown yellowish colour (Fig. 2). The removal of these samples only moderately improve the correlation of $\mathrm{Hg}$ contents with $\mathrm{TOC}\left(\mathrm{R}^{2}=0.56\right.$ versus 0.47$)$, suggesting that neither changes in TOC content nor the differential loss of TOC relative to $\mathrm{Hg}$ can entirely explain the recorded trends.

Alternatively or additionally, recent studies suggested Hg could also be hosted by pyrite rather than by organic matter (e.g. Shen et al., 2019; Fantasia et al., 2019). The high proportions of goethite in some levels of the upper part of the studied section point to a late diagenetic transformation of pyrite into goethite, so that pyrite contents cannot be directly used to constrain this possible influence. Assuming that As and Fe contents better trace the original pyrite contents, their good correlation with $\mathrm{Hg}$ contents (As: $\mathrm{R}^{2}=0.6$; Fe: $\mathrm{R}^{2}=0.76$ ), suggests a strong influence of pyrite contents on $\mathrm{Hg}$ contents at Roqueredonde. A similar relationship has been reported for pyritised wood fragments in Peniche section (Fantasia et al., 2019). Nevertheless, $\mathrm{Hg} / \mathrm{As}$ and $\mathrm{Hg} / \mathrm{Fe}$ ratios show a substantial Hg enrichment in the negative CIE interval (Fig. 6), again indicating that higher Hg contents cannot entirely be explained by enhanced pyrite formation.

Finally, $\mathrm{Hg}$ contents show the highest correlation with $\mathrm{Ni}$ contents as traced by elemental $\left(R^{2}=0.92 ; n=21\right)$ and $\mathrm{NiO}$ analyses $\left(R^{2}=0.91 ; n=32\right)$, whereas the MARs of these two elements show a poorer correlation $\left(R^{2}=0.42\right)$. The Hg MAR shows an even poorer correlation with the MARs of other elements $\left(\mathrm{R}^{2}<0.1\right)$. Interestingly, peaks in $\mathrm{Ni}$ contents across the Permo-Trias boundary have been also attributed to higher volcanic activity owing to the high $\mathrm{Ni}$ contents of the associated mantle plume material (Rampino et al., 2017). We note, however, that Ni is a RSTE that becomes substantially enriched in sulphides under euxinic conditions (Algeo and Maynard, 2004). Although further work 
is clearly needed to better constrain the factors controlling sedimentary Hg contents, we conclude that the $\mathrm{Hg}$ record at Roqueredonde is compatible with a peak of volcanic $\mathrm{Hg}$ supply that has been exacerbated by local changes in detrital fluxes and oxygenation.

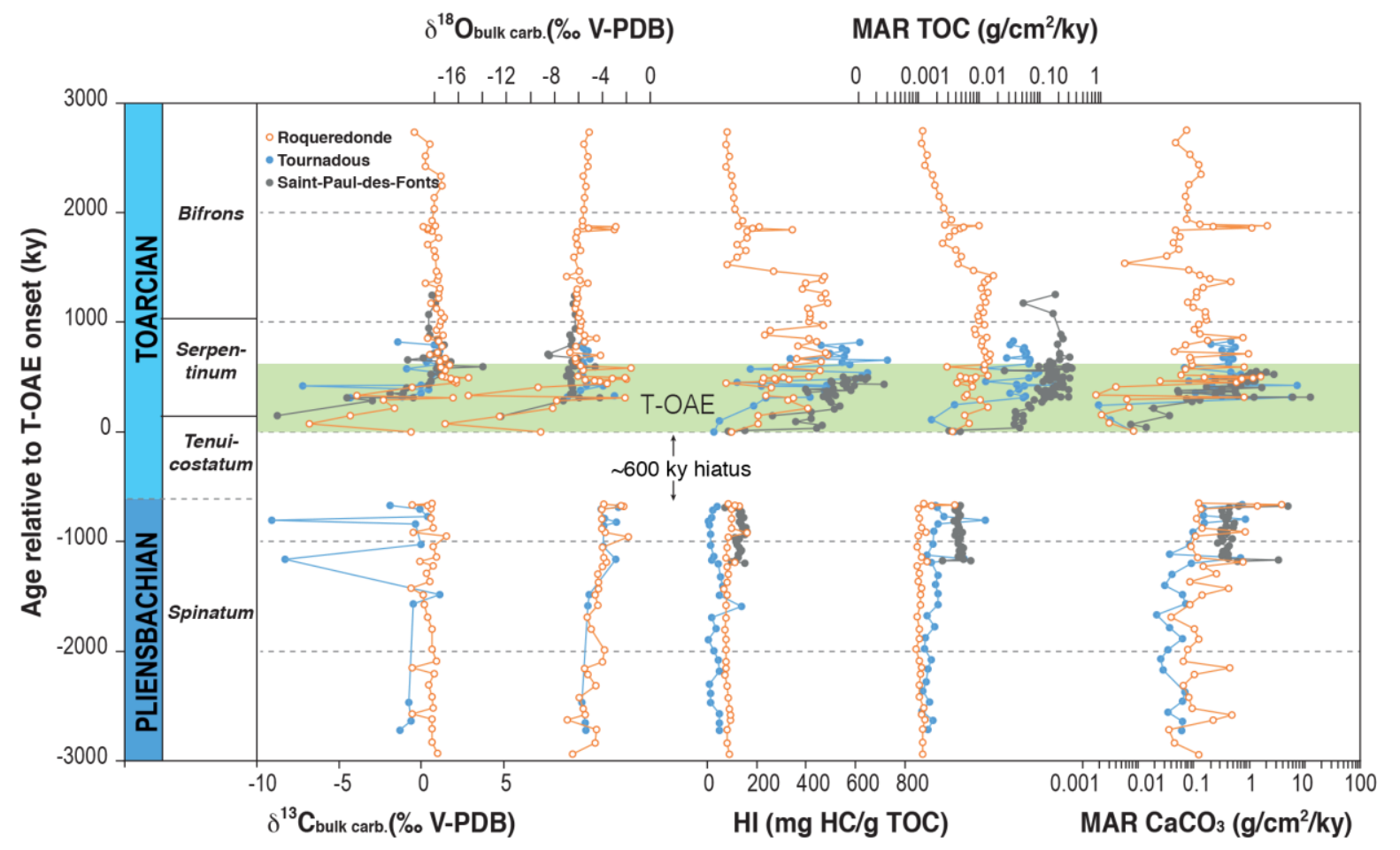

Figure 11: Age model applied on the Roqueredonde, Tournadous and Saint-Paul-des-Fonts sections. Reconstructed MAR (mass accumulation rate) of carbon and oxygen bulk carbonate isotopes, hydrogen index, and TOC values.

\section{Changes in weathering, hydrology and climate}

The CIA and WIP indices have been widely used to infer climatic fluctuations and weathering intensity (Nesbitt and Young, 1982; Fedo et al., 1997; Price and Velbel, 2003). Perennially hot and humid climate are indicated by CIA values ranging from 80 to 100 , warm and seasonal climate by $60-80$ values, and cold and/or arid climate by $<60$ values (Nesbitt and Young, 1982, 1989). Based on the alkali and alkaline earth metals (sodium, potassium, magnesium and calcium), which are favourably mobilised in areas of intense chemical weathering, the WIP index has been classically used to evaluate the weathering profile (Price and Velbel, 2003). However, both indices cannot reasonably be used in pure carbonate limestone where clastic element contents are too weak (McLennan, 1993). The strong correlation between detritus curve and WIP (Fig. 8; $\left.\mathrm{R}^{2}=0.96\right)$, suggests that high WIP values indicate periods of increasing physical weathering whereas low WIP values indicate intense chemical weathering (Fig. 8). The 
Pliensbachian interval records (spinatum Zone) are relatively low CIA values (minimum 74), and relatively high WIP values, suggesting a cold and/or arid climatic trend, in agreement with cooler seawater and atmospheric temperatures during the latest Pliensbachian (e.g. Bailey et al., 2003; Rosales et al., 2006, Suan et al., 2008, 2010; Harazim et al., 2013; Baghli et al., 2020; Schöllhorn et al., 2020). However, two points (RQ-30 and 31) in the uppermost part of the spinatum Zone exhibit significant CIA values indicating of warmer and more humid conditions, at odds with existing $\delta^{18} 0$ data, in particular from the Grands Causses Basin (Fig. 8; Harazim et al., 2013). We attribute this discrepancy to the diagenetic nature of the concretionary limestone that show very high $\mathrm{CaO}$ content, which decrease the signal to noise ratio of other elements and hampers their interpretation in terms of paleoenvironmental changes. The increase in CIA and decrease in WIP recorded across the Toarcian negative CIE suggest a change toward chemical weathering under warm and more humid conditions (Fig. 8).

A comparable increase in weathering during the negative CIE has been suggested for several sites of the NW Tethyan realm using independent proxies including clay mineralogy (Duarte, 1998; Dera et al., 2009; Hermoso and Pellenard, 2014; Fantasia et al., 2018a, 2019), CIA index (Montero-Serrano et al., 2015; Fu et al., 2017; Fantasia et al., 2018a, 2019), and ${ }^{1870 s / 188}$ Os and $\delta^{44 / 40}$ Ca data (Cohen et al., 2004; Brazier et al., 2015; Percival et al., 2016; Them II et al., 2017a). An intensification of the hydrological cycle is supported by sedimentological evidence for increased storm activity (Suan et al., 2013; Krenker et al., 2015). Warmer conditions are supported by oxygen isotope data (e.g. Bailey et al., 2003; Rosales et al., 2006, Suan et al., 2008, 2010; Harazim et al., 2013). The increase in detrital input (Fig. 8) during this interval also could indicate enhanced continental detrital input linked to increased precipitations, but can also be related to strong decrease in carbonate production (Mattioli et al., 2009; Suan et al., 2008).

Above the negative CIE interval, lower CIA value at Roqueredonde (Fig. 8) indicate a change toward less warm and drier conditions, in agreement with the cooling suggested by oxygen isotope data from coeval European succession (e.g., Bailey et al., 2003; Rosales et al., 2006, Suan et al., 2008, 2010; Harazim et al., 2013; Ullmann et al., 2020). The two high CIA values recorded in bifrons Zone are also located in diagenetic limestone beds are should therefore be interpreted with caution (Fig. 8). 


\section{Changes in salinity}

Several lines of evidence in the new and published records in the Grands Causses Basin indicate that the acceleration of the hydrological cycle at the T-OAE onset led to higher freshwater input. First, the extremely low bulk carbonate $\delta^{18} 0$ values (down to 17.1\%o) in this interval suggest a strong freshwater input (Figs. 5 and 9), although the very low $\mathrm{CaCO}_{3}$ contents of the corresponding samples ( $<2$ wt. \%) could also point to later diagenetic overprint due to meteoric pore-water circulation. Unpublished phosphate $\delta^{18} 0$ values of fish apatite phosphate across the "Leptolepis bed" of the exaratum Subzone in Saint-Paul-des-Fonts also point to very low values (down to 14.8\% SMOW; Suan, 2005) compatible with a strong freshwater influence. This interpretation is also supported by the low HI/OI ratios in the negative CIE interval, which point to a high terrestrial organic matter influx (Fig. 9; highlighted in light blue). A similar pattern has been reported in the Pueblo Basin across the Cenomanian-Turonian transition, where extremely low $\delta^{18} 0$ values recorded in Hedbergella coincide with high OI and foraminifera assemblage indicative of higher fresh water influx (Keller et al., 2004).

Lower $\mathrm{Sr} / \mathrm{Ba}$ ratios recorded at Roqueredonde in the negative CIE interval (Fig. 9) could also point to a decrease in salinity, which tend to favour $\mathrm{BaSO}_{4}$ over $\mathrm{SrSO}_{4}$ precipitation (Chen et al., 1997). The ranking of $\mathrm{Sr} / \mathrm{Ba}$ absolute values is not attempted here to discriminate freshwater, brackish or marine conditions because of the large changes in the amount of calcite contents that typically host large amounts of Sr (Wei and Algeo, 2020). An anomalous salinity is also compatible with the changes in the fossil content of the succession. The basal part of the negative CIE interval is indeed marked by a drop in abundance and diversity of ammonoids that are represented by a couple of specimens belonging to only one genus and one species (Tiltoniceras cf. antiquum; Fig. 3). No other marine macrofossils such as belemnites or bivalves have been found in the same interval, suggesting adverse environmental conditions for these groups. The negative CIE interval is also notable for its very low $\mathrm{CaCO}_{3}$ contents (Figs. 4 and 5). Comparably low $\mathrm{CaCO}_{3}$ contents, combined with the low abundance and unusual assemblages of calcareous nannofossils in coeval strata of the nearby sites of Tournadous and Saint-Paul-des-Fonts have been attributed to high freshwater input (Mailliot et al., 2009). 
A major decrease in seawater salinity at the T-OAE onset has been also suggested in the Cleveland Basin and SW German basin (Röhl et al., 2001) based on stable isotope and elemental evidence (Fig. 9; Bailey et al., 2003; McArthur et al., 2008, McArthur, 2019; Wei and Algeo, 2020; Remírez and Algeo, 2020a). Numerical simulations indicate that this decrease in salinity in the northern part of the European seaway may have been favoured by a warming-induced increase in continental runoff and by the proximity of large landmasses experiencing more humid conditions (Dera and Donnadieu, 2012; Ruvalcaba Baroni et al., 2018). Our new data, combined with published geochemical data, therefore support the hypothesis of strong salinity stratification during the T-OAE onset (Schouten et al., 2000; Röhl et al., 2001; Dickson et al., 2017; McArthur et al., 2008, 2019; Wei and Algeo, 2020; Remírez and Algeo, 2020a).

The interval above the negative CIE between 3.7 and $4.2 \mathrm{~m}$ records an increase to background $\delta^{18} \mathrm{O}_{\text {carb values }(-6 \%)}$ and a substantial increase in $\mathrm{HI} / \mathrm{OI}$ and $\mathrm{Sr} / \mathrm{Ba}$ ratios, suggesting a return to more marine conditions (highlighted in dark blue in Fig. 9). A return to normal marine conditions is also supported by the increase in ammonite abundance and diversity at $3.7 \mathrm{~m}$ and the reappearance of belemnite rostra at $3.9 \mathrm{~m}$ (Fig. 9).

\section{Spatiotemporal changes in preservation and fluxes of organic matter}

One of the most remarkable aspects of our results is that the maximum reconstructed MAR TOC values occur between 3.7 and $5 \mathrm{~m}$, i.e., well above the negative CIE (Fig. 11). Lowest bottom water oxygenation during this long-lived episode $(>1000$ ky according to our conservative age model; Fig. 11) is indicated by the highest HI values (i.e., highest proportions of labile, oxidation-prone hydrocarbons in the buried organic matter). This interval also records the highest Corg/Ptot ratio (higher than the Redfield ratio; 106:1; Redfield, 1958), consistent with higher P release under poorly-oxygenated conditions (Fig. 5). Although additional measurements would be needed to better capture their long-term trends, $\mathrm{Mo} / \mathrm{Al}, \mathrm{U} / \mathrm{Ca}$ and $\mathrm{V} / \mathrm{Ca}$ ratios also reach their highest values around $4 \mathrm{~m}$, well above the negative CIE interval (Fig. 7). Further insight on oxygenation can be gained using the TE/Al versus TOC cross-plot of Algeo and Maynard (2004; Fig. 10a). The U, V, Mo, Ni and Cu RSTE patterns suggest anoxic conditions during the T-OAE CIE and post T-OAE intervals (Fig. 10a). None of analysed samples plot on the euxinic field because this method assumes an arbitrary lower TOC threshold of $10 \mathrm{wt} . \%$ 
(Fig. 10). Nevertheless, the higher $\mathrm{U} / \mathrm{Al}$ and Mo/Al ratio of post-T-OAE samples relative to T-OAE samples mimic the euxinic trend, suggesting the presence of appreciable amounts hydrogen sulphides in the water column (Fig. 10a).
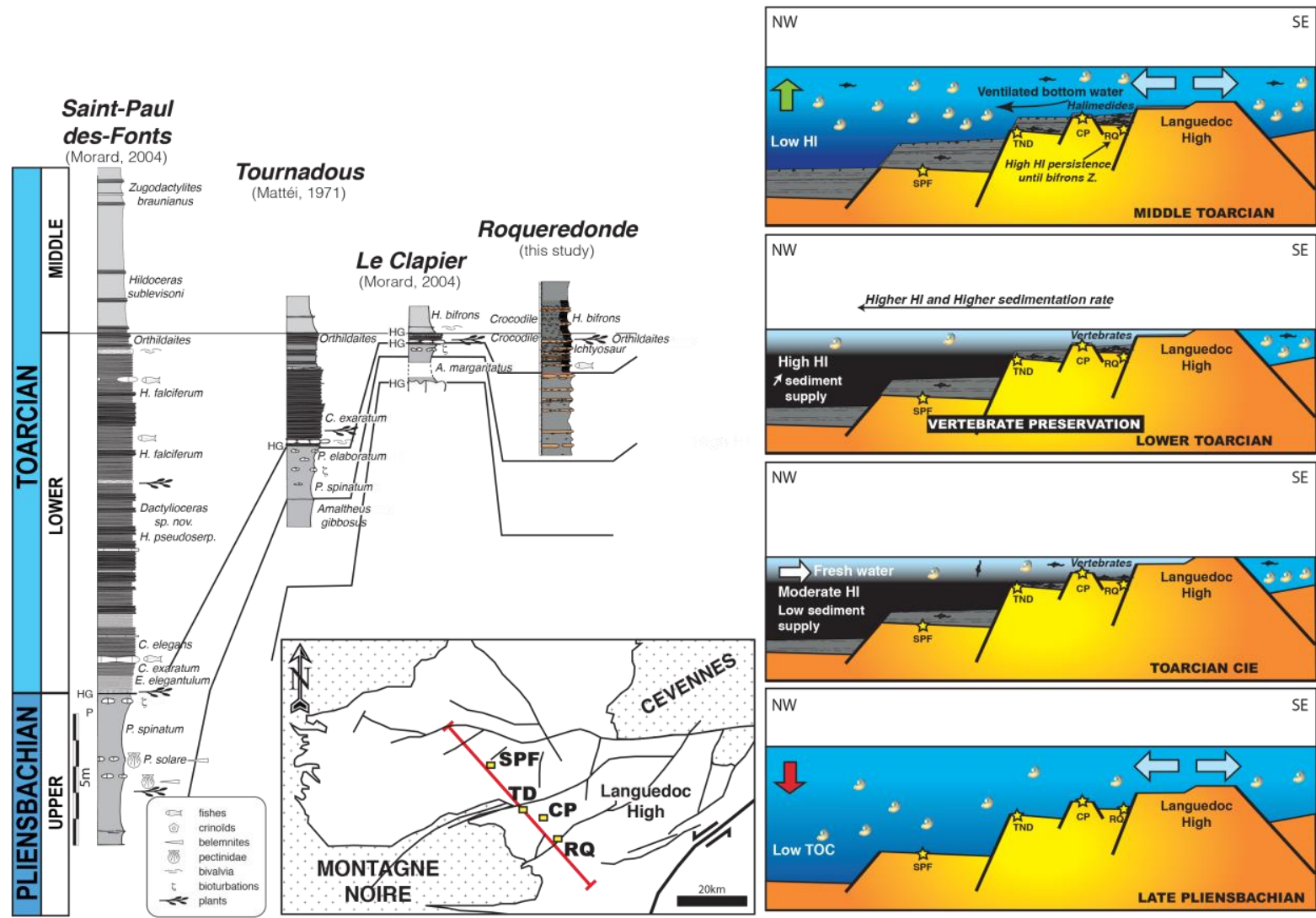

Figure 12: Summary sketch of the Grands Causses Basin model deposition. Stratigraphic logs and locations of the Saint-Paul-des-Fonts (SPF) and Le Clapier (CP) sections from Morard (2004), Tournadous (TD) section from Mattéi (1971), and Roqueredonde section (this study).

Altogether, these various geochemical data indicate that the minimum of oxygenation and maximum of organic matter preservation post-dated by several hundreds of kyrs the marked carbon cycle perturbations and associated environmental changes reflected by the negative CIE. This discrepancy is at odds with most models suggested so far to explain the changes in oxygenation recorded during the T-OAE, in which warming-induced salinity stratification and high productivity lead to a strong decline in bottom water oxygenation and maximum carbon burial (e.g. Röhl et al., 2001; Dickson et al., 2017; McArthur et al., 2008, 2019; Wei and Algeo, 2020; Remírez and Algeo, 2020a).

In this regard, it is noteworthy that the low MAR TOC during the T-OAE onset in our reconstructions are linked to the very low calcite contents $(<4$ wt. \%) characterizing 
the negative CIE interval (Fig. 5). It could be argued that our assumption of a constant detrital flux is incorrect and that these very low $\mathrm{CaCO}_{3}$ contents reflect a transient episode of higher dilution by detrital material. If so, such an increase in detrital influx would imply an expansion of the negative CIE interval relative to coeval records showing higher $\mathrm{CaCO}_{3}$. At Roqueredonde, the interval comprised between the first occurrence (FO) Tiltoniceras cf. antiquum and the Leptolepis bed (core of the negative CIE; $0.25 \mathrm{~m}$ ) occupies less than $20 \%$ of the interval defined by the FO of Tiltoniceras cf. antiquum to the FO of Orthildaites douvillei (1.45 m; Figs. 3 and 5). This ratio is also less than $20 \%$ at Tournadous and Saint-Paul-des-Fonts. At Dotternhausen, where background $\mathrm{CaCO}_{3}$ contents also oscillate around $50 \%$ but do not drop below 20 wt. \% in the negative CIE interval, the same ratio exceeds 40\% (Röhl et al., 2001; Suan et al., 2015). These comparisons strongly suggest that the CIE interval in the Grands Causses Basin is much condensed relative to younger and older strata due to very low $\mathrm{CaCO}_{3}$ fluxes.

Evidence for much very reduced sedimentation rates across the T-OAE onset has major implications for the spatiotemporal distribution of organic burial across the TOAE in the studied basin. Studies of modern marine sediments have shown that MAR TOC is linearly correlated with bulk sedimentation rates, even in anoxic settings (Schoepfer et al., 2015). Mechanistically, this relationship occurs because lower sedimentation rates greatly increase exposure time of organic matter on the seafloor and therefore enhanced its degradation, even under poorly oxygenated. This very simple mechanism could certainly appropriately explain why environmental changes theoretically favourable to enhanced organic matter preservation during the T-OAE onset (salinity stratification, higher nutrient input) did not led to the highest MAR TOC.

We therefore suggest that high runoff and low salinity across the T-OAE onset were detrimental to most carbonate producers, including calcareous nannofossils, hence strongly reducing $\mathrm{CaCO}_{3} \mathrm{MAR}$ and hence bulk sedimentation rates. Interestingly, recent boron isotope data from Portugal suggest that $\mathrm{pH}$ dropped to very low values during this time interval due to massive $\mathrm{CO}_{2}$ injection (Mueller et al, 2020). Because water saturation relative to calcite and aragonite decrease with salinity, such a drop in $\mathrm{pH}$ would have been exacerbated in the high influx of freshwater into the Grands Causses basin. Surface waters may have approached under-saturation and hence excluded most aragonitic and calcite producers. In any case, the large drop in $\mathrm{CaCO}_{3}$ fluxes would have 
increased dramatically the residence time of organic matter and RSTE on the seafloor, favouring their repeated remineralisation, for instance during short-lived episodes of improved oxygenation interrupting longer periods of oxygen-depletion. During to the post-negative CIE interval, freshwater fluxes most likely diminished and sedimentation rates resumed to pre-event values, whereas oxygenation did not improve substantially, ultimately leading to higher TOC MAR and RSTE contents (Fig. 9, 10b).

One testable consequence of this hypothesis is that the burial and quality of organic matter should increase with increasing sedimentation rates, not only temporally, but also laterally. This prediction is in excellent agreement with the reconstructed TOC MAR at Tournadous and Saint-Paul-des-Fonts, where TOC MAR and HI values increase markedly with sedimentation rates (Fig. 11). This strong lateral variability of Toarcian accumulation rates of the Grands Causses Basin has been also recognised by Trumpy (1983) and Morard (2003), who attributed them to variable accommodation space due to the tectonic structuration of the basin. Nevertheless, to our knowledge, the physical mechanisms through which both detrital and carbonate sediments would have preferentially accumulated in deeper areas have not been identified. One possibility is that the sediments in shallower locations have been winnowed and transported to deeper locations through bottom currents, but we did not observe any preferential orientation of belemnite rostra occurring in very high abundance on bedding planes above $3.9 \mathrm{~m}$ (Fig. 2). No sedimentary structure indicative of gravity transport (turbidites, slumps, debris flow deposits) or of storm activity has been recorded in the succession. Down-slope transport, if any, was thus likely limited to fine-grained material.

There are no documented coarse siliciclastic deposits of early Toarcian age in the southern and western part of the Basin that could testify that the corresponding crystalline basements were exposed at the time of deposition. We therefore speculate that the majority of the terrigenous material was sourced from distant continental areas such as the Cévennes or Massif Central (Fig. 2) and transited through sediment plumes across the basin. Accordingly, fine-grained terrigenous sediments preferentially accumulated in the topographic lows (e.g., Saint-Paul-des-Fonts) and only occasionally reached the submarine highs (e.g., Roqueredonde). Similarly, the basinward increase in MAR $\mathrm{CaCO}_{3}$ could reflect the supply of carbonate mud from small, distant carbonate platforms. 
We note that the highest TOC MAR reconstructed for SPF $\left(0.3 \mathrm{~g} / \mathrm{cm}^{2} / \mathrm{kyr}\right.$ or 3 $\mathrm{g} / \mathrm{m}^{2} / \mathrm{yr}$ ) are low relative to those estimated for modern anoxic settings. These values are comparable to those reported in oxygen-deficient sites of the Black Sea (3.1-4.8 $\mathrm{g} / \mathrm{m}^{2} / \mathrm{yr}$; Kuypers et al., 2002) but are 2 to 10 lower than those estimated for other modern anoxic sites (6 to $39 \mathrm{~g} / \mathrm{m}^{2} / \mathrm{yr}$; Kuypers et al., 2002) as well as CenomanianTuronian OAE-2 sites (ranging between 9 and $26 \mathrm{~g} / \mathrm{m}^{2} / \mathrm{yr}$; Kuypers et al., 2002). Beyond the classically discussed role of productivity and preservation, these sharp contrasts highlight the importance of accommodation space (shallow restricted basin or marginalmarine shelf) and sediment supply as major drivers of carbon burial in oxygen-deficient settings (Schoepfer et al., 2015).

The persistence of anoxic conditions and high TOC burial until the bifrons Zone, well above the T-OAE CIE is not unusual and has been recognised in numerous sites in SW Germany (e.g. Röhl et al., 2001), France (Hermoso et al., 2013), England (e.g. McArthur 2008) or Siberia (e.g. Suan et al., 2011). The strata recording high TOC burial and strong oxygen depletion generally extend well above the negative CIE in epicontinental sections in NW Europe (e.g. Remírez and Algeo, 2020b), whereas they are restricted to the negative CIE interval in more open marine sections of the SE Mediterranean domain (e.g. Mattioli et al., 2004; Kafousia et al. 2011). The prolonged development of oxygen-depletion in areas close to the large landmasses of Laurasia was thus certainly facilitated by higher runoff and nutrients input (Dera et al., 2009, 2011; Philippe et al., 2017), but also by ocean circulation patterns (Ruvalcaba et al., 2018). Clay mineral and wood assemblages indicate the occurrence of humid climate belt in boreal and NW European domains and a prolonged episode of higher humidity broadly corresponding to the serpentinum-bifrons zones (e.g. Dera et al., 2009, 2011; Philippe et al., 2017). Such evidence would suggest a dominant role for enhanced runoff and nutrient from the input in the prolonged development of anoxia in boreal seas and NW Europe, including the studied site.

This history of oxygenation is also supported by the occurrence of the ichnogenus Halimedides in the upper part of the sublevisioni Subzone (bifrons Zone; Fig. 3) at Roqueredonde. This organism is mainly well known in Cretaceous periods (e.g. Gaillard and Olivero, 2009; Uchman et al., 2013), and in the Cenozoic periods (Caruso et al., 2011), but is rare in Lower Jurassic strata (Rodríguez-Tovar et al., 2019). The Halimedides tracemaker is interpreted as an opportunistic organism that colonised 
firmground sediments under well-oxygenated seafloor conditions, favouring its agrichnial/sequestrichnia behaviour (Gaillard and Olivero, 2009; Rodríguez-Tovar et al., 2019). Halimedides has been recently documented by Rodríguez-Tovar et al. (2019) in Toarcian strata the Lusitanian basin, where it also occurs after the T-OAE interval. Occurrences of Halimedides just above the T-OAE interval in the levisioni Zone in the Lusitanian basin have been attributed to the re-establishment of more oligotrophic surface conditions and improved bottom waters ventilation in a context of sea-level rise. At Roqueredonde, the first occurrence of Halimedides is delayed in the bifrons Zone and is coeval with the marked decline in TOC contents and HI values above $5.2 \mathrm{~m}$. This delayed appearance therefore support to the longer persistence of poorly oxygenated in S France. Interestingly, the association of Halimedides with limestone banks containing densely packed bivalve accumulations at 5.5 and $5.6 \mathrm{~m}$ (Fig. 2) further suggest the reestablishment of more marine conditions was followed by the development of stronger bottom water currents (Rodríguez-Tovar et al., 2019).

\section{Implications for vertebrate preservation}

The three vertebrate-yielding horizons identified during the field campaigns at Roqueredonde occur between 4.15 and 5.15, i.e., in the interval of maximum TOC and HI values. It thus appears that the preservation of vertebrate specimens was favoured by low bottom water oxygenation, in line with previous findings from SW Germany (Martill, 1993; Lindgren et al., 2018). The three identified horizons show very low CaCO3 contents (Fig. 5), which, as discussed above, imply very reduced sedimentation rates and hence exposure on the seafloor for some considerable time. The disarticulated state of the specimen excavated at $4.15 \mathrm{~m}$ and $4.4 \mathrm{~m}$ indicate a substantial amount of postdepositional displacement by weak bottom currents or by scavengers. In any case, their preservation state implies that weakly oxygenated conditions occurred at least intermittently after it is deposition on the seafloor, consistent with the slightly lower HI values recorded in these horizons relative to the adjacent beds. By contrast, the articulated nature of the ichthyosaur specimen including soft-tissue preservation suggests very limited post-depositional displacement, which might be compatible with rapid sinking into a soupy-substrate (Martill, 1993). Further geochemical data constraining the exact provenance of this specimen would help to reconstruct conditions favourable to its exceptional preservation. 
As discussed above, our data show that the Roqueredonde section is extremely condensed relative to adjacent sections of the Grands Causses Basin. The interval comprised between the first occurrence (FO) of T. antiquum at base of the Toarcian and the FO of Orthildaites douvillei occupies $1.45 \mathrm{~m}$ at Roqueredonde, while it occupies $3.2 \mathrm{~m}$ at Tournadous (Pinard et al., 2014) and $12.1 \mathrm{~m}$ at Saint-Paul-des-Fonts (Morard, 2003). Accordingly, this interval (roughly the uppermost semicelatum Subzone + serpentinum Zone) is 2.6 and 8.3 times more expanded, respectively, in these two sections, pointing to a strong basinward increase in sediment accumulation over a distance of less than 20 $\mathrm{km}$ during the early Toarcian interval. In SW Germany, the same interval (FO of $T$. antiquum to $\mathrm{FO}$ of $O$. douvillei) occupies more than $4.5 \mathrm{~m}$ at Dotternhausen and is reduced to only $2 \mathrm{~m}$ at Ohmden (Riegraf et al., 1984), located $80 \mathrm{~km}$ to the northeast. The more condensed sites of Ohmden and in the immediate vicinity (Holzmaden, Bad Boll) have yielded hundreds (if not thousands) of vertebrate skeletons and are some of the most prolific fossiliferous sites of the Jurassic (Hauff and Hauff, 1981). These comparisons indicate that the combination of extremely low sedimentation rate and strong oxygen depletion are the key requirements to preserve and accumulate numerous marine vertebrate remains (Fig. 12). A more systematic screening of these two criterions may allow to identify locate new fossiliferous sites and hence fill geographic or temporal gaps in the fossil record.

\section{Conclusions}

- A high-resolution inorganic and organic carbon isotopes coupled to highresolution ammonites biostratigraphy permit to establish a robust framework to the Pliensbachian-Toarcian interval at the Roqueredonde section, and the presence of significant hiatus of the T-OAE onset.

- Mercury appear to be link to the Karroo Ferrar volcanism, but still enhanced by others factors like increased organic matter and terrestrial inputs and/or pyrite.

- CIA and WIP suggest a climatic change from a cold and/or arid climatic trend during the latest Pliensbachian toward warmer and more humid conditions coeval with several sites of the NW Tethyan realm. Above the negative CIE interval, a change toward less warm and drier conditions is observed, consistent with the cooling observed in Europe. 
- An acceleration of the hydrological cycle at the T-OAE onset, leading to higher freshwater input is observed in the Grands Causses, suggested by a drop in abundance and diversity of ammonoids, absence of other marine macrofossils such as belemnites or bivalves, and geochemical proxies as $\mathrm{HI} / \mathrm{OI}$ and $\mathrm{Sr} / \mathrm{Ba}$. A return to normal marine conditions occurs above the CIE.

- Anoxic condition during the T-OAE CIE is confirmed by high RSTE enrichment factor associated to laminated black shales.

- The maximum of organic matter preservation did not took place during the TOAE onset, suggesting an improvement to current models explaining the changes in oxygenation recorded during the T-OAE, in which warming-induced salinity stratification and high productivity lead to a strong decline in bottom water oxygenation and maximum carbon burial.

- Evidence for much very reduced sedimentation rates across the T-OAE onset has major implications for the spatiotemporal distribution of organic burial across the TOAE in the studied basin.

The MAR TOC appears correlated with bulk sedimentation rates, due to lower sedimentation rates which greatly increase exposure time of organic matter on the seafloor and therefore enhanced its degradation, even under depleted oxygen conditions. This explains why environmental changes theoretically favourable to enhanced organic matter preservation during the T-OAE onset (salinity stratification, higher nutrient input) did not led to the highest MAR TOC.

-The combination of an extreme low sedimentation rate and strong anoxia allow the preservation and the great accumulation of numerous marine vertebrates remains.

\section{Acknowledgements}

We warmly thank the Paleorhodania association member for their participation in the 2017-2020 field campaigns: Olivier 'Wilsa' Ambrosini, Céline Banet, Thomas Croissant, Vincent Fernandez, Alex Lena, Kellie Poure, Thérèse Quartiero and Estel Sarroca. We warmly thank the Musée de Lodève (Hérault, France) for administrative, technical, and financial support of the excavations, Gérard Mareau (Groupe archéologique Lodévois) without which the field campaigns would have been impossible. We warmly thank Tiffany Monnier, Sandrine Fattore, Camila Peguiron and 
Alexia Secretan for laboratory assistance, and Olivier Reubi for major and trace elements analyses (University of Lausanne, Switzerland).

\section{Funding}

The field campaigns were partly supported by the ANR Oxymore (ANR-18-CE31-0020) and the Lodévois and Larzac Community of Municipalities, fieldworks of JS were partly financed from projects APVV 17-0555 and VEGA 2/0169/19, and the laboratory analyses were supported by the University of Lausanne.

\section{References}

Adatte, T., Stinnesbeck, W. and Keller, G. 1996. Lithostratigraphical and mineralogic correlations of near K/T boundary clastic sediments in northeastern Mexico: implications for origin and nature of deposition. Geological Society of America Special Paper, 307, 211-226.

Algeo, T.J. and Maynard, J.B. 2004. Trace-element behavior and redox facies in core shales of Upper Pennsylvanian Kansas-type cyclothems. Chem. Geol., 206, 289318.

Arthaud, F. and Matte, P. 1975. Les décrochements tardi-hercyniens du Sud-Ouest de l'Europe. Géométrie et essai de reconstitution des conditions de la déformation. Tectonophysics, 25, 139-171, http://dx.doi.org/10.1016/0040-1951(75)90014-1

Baghli, H., Mattioli, E., Spangenberg, J.E., Bensalah, M., Arnaud-Godet, F., Pittet, B. and Suan, G. 2020. Early Jurassic climatic trends in the south-Tethyan margin. Gondwana Res., 77, 67-81.

Bailey, T.R., Rosenthal, Y., McArthur, J.M., van de Schootbrugge, B. and Thirlwall, M.F. 2003. Paleoceanographic changes of the Late Pliensbachian-Early Toarcian interval: a possible link to the genesis of an Oceanic Anoxic Event. Earth Planet. Sci. Lett., 212 (3-4), 307-320.

Bardet, N., Godefroit, P. and Sciau, J. 1999. A new elasmosaurid plesiosaur from the Lower Jurassic of southern France. Palaeontology, 42(5), 927-952.

Behar, F., Beaumont, V. and Penteado, H.L.D. 2001. Rock-Eval 6 technology: performances and developments. Oil Gas Sci. Technol., 56 (2), 111-134. 
Boulila, S. and Hinnov, L.A. 2017. A review of tempo and scale of the early Jurassic Toarcian OAE: implications for carbon cycle and sea level variations. Newsletters on Stratigraphy, 50, 363-389.

Brazier, J.-M., Suan, G., Tacail, T., Simon, L., Martin, J.E., Mattioli, E., Balter, V., 2015. Calcium isotope evidence for dramatic increase of continental weathering during the Toarcian oceanic anoxic event (Early Jurassic). Earth Planet. Sci. Lett., 411, 164-176.

Burgess, S.D., Bowring, S.A., Fleming, T.H. and Elliot, D.H. 2015. High-precision geochronology links the Ferrar large igneous province with early-Jurassic ocean anoxia and biotic crisis. Earth Planet. Sci. Lett., 415, 90-99.

Caruso, C., Sonnino, M. and Uchman, A., 2011. Preliminary ichnological observations on the Trubi Formation (Lower-Middle Pliocene) near the village of Palizzi Marina (southern Ionian Calabria). Rend. Online Soc. Geol. It., 17, 53-57.

Cecca, F. and Macchioni, F. 2004. The two Early Toarcian (Early Jurassic) extinction events in Ammonoids. Lethaia, 37, 35-56.

Charbonnier, G., Adatte, T., Föllmi, K.B. and Suan, G. 2020. Effect of intense weathering and post-depositional degradation of organic matter on $\mathrm{Hg} / \mathrm{TOC}$ proxy in organic-rich sediments and its implications for deep-time investigations. Geochem. Geophys. Geosyst e22109.

Charbonnier, G., Morales, C., Duchamp-Alphonse, S., Westermann, S., Adatte, T. and Föllmi, K.B. 2017. Mercury enrichment indicates volcanic triggering of Valanginian environmental change. Nat. Sci. Rep. 1-6.

Chen Z. Y., Chen Z. L. and Zhang W. G. 1997. Quaternary stratigraphy and trace-element indices of the Yangtze Delta, Eastern China, with special reference to marine transgressions. Quat. Res., 47(2), 181-191.

Cohen, A.S., Coe, A.L., Harding, S.M. and Schwark, L. 2004. Osmium isotope evidence for the regulation of atmospheric CO2 by continental weathering. Geology, 32, 157160.

Danise, S., Twitchett, R.J. and Little, C.T.S. 2015. Environmental controls on Jurassic marine ecosystems during global warming. Geology, 43, 263-266.

Dera, G. and Donnadieu, Y. 2012. Modeling evidences for global warming, Arctic seawater freshening, and sluggish oceanic circulation during the Early Toarcian anoxic event. Paleoceanography, 27, PA2211. 
Dera, G., Neige, P., Dommergues, J.L. and Brayard, A. 2011. Ammonite paleobiogeography during the Pliensbachian-Toarcian crisis (Early Jurassic) reflecting paleoclimate, eustasy, and extinctions. Glob. Planet. Chang., 78 (3-4), 92-105.

Dera, G., Pellenard, P., Neige, P., Deconinck, J.-F., Pucéat, E. and Dommergues, J.-L. 2009. Distribution of clay minerals in Early Jurassic Peritethyan seas: palaeoclimatic significance inferred from multiproxy comparisons. Palaeogeogr. Palaeoclimatol. Palaeoecol., 271, 39-51.

Dickson, A.J., Gill, B.C., Ruhl, M., Jenkyns, H.C., Porcelli, D., Idiz, E., Lyons, T.W. and van den Boorn, S.H. 2017. Molybdenum-isotope chemostratigraphy and paleoceanography of the Toarcian Oceanic Anoxic Event (Early Jurassic). Paleoceanography, 32 (8), 813-829.

Duarte, L.V., 1998. Clay minerals and geochemical evolution in the Toarcian-lower Aalenian of the Lusitanian basin (Portugal). Cuad. Geol. Iber., 24, 69-98.

Eaton, A.D., Clesceri, L.S. and Greenberg, A.E. 1995. Standard Methods for examination of Water and Waste Water, IXI, 4113-4114.

Espitalié, J., Deroo, G. and Marquis, F. 1985. La pyrolyse Rock-Eval et ses applications. Revue de l'Institut Français du Pétrole, 40, 563-579.

Fantasia, A., Adatte, T., Spangenberg, J.E., Font, E., Duarte, L.V. and Föllmi, K.B. 2019. Global versus local processes during the Pliensbachian-Toarcian transition at the Peniche GSSP, Portugal: a multi-proxy record. Earth Sci. Rev. 102932.

Fantasia, A., Föllmi, K.B., Adatte, T., Bernárdez, E., Spangenberg, J.E. and Mattioli, E. 2018a. The Toarcian oceanic anoxic event in southwestern Gondwana: an example from the Andean Basin, northern Chile. J. Geol. Soc. Lond., 175 (6), 883902.

Fantasia, A., Föllmi, K.B., Adatte, T., Spangenberg, J.E., Montero-Serrano, J.-C., 2018b. The Early Toarcian oceanic anoxic event: Paleoenvironmental and paleoclimatic change across the Alpine Tethys (Switzerland). Global and Planetary Change, 162, 53-68.

Fedo, C.M., Nesbitt, H.W. and Young, G.M. 1995. Unraveling the effects of potassium metasomatism in sedimentary rocks and paleosols, with implications for paleoweathering conditions and provenance. Geology, 23, 921-924. 
Fedo, C.M., Young, G.M. and Nesbitt, G.M. 1997. Paleoclimatic control on the composition of the Paleoproterozoic Serpent Formation, Huronian Supergroup, Canada: A greenhouse to icehouse transition. Precambrian Research, 86, 201-223.

Fonseca, C., Mendonça Filho, J.G., Lézin, C., Duarte, L.V. and Fauré, P. 2018. Organic facies variability during the Toarcian Oceanic Anoxic Event record of the Grands Causses and Quercy basins (southern France). Int. Jour. Coal Geol., 190, 218-235.

Font, E., Adatte, T., Sial, A.N., Lacerda, L.D., Keller, G., and Punekar, J. 2016. Mercury anomaly, Deccan volcanism, and the end-cretaceous mass extinction. Geology, 44, 171-174.

French, K.L., Sepúlveda, J., Trabucho-Alexandre, J., Gröcke, D.R. and Summons, R.E. 2014. Organic geochemistry of the early Toarcian oceanic anoxic event in Hawsker Bottoms, Yorkshire, England. Earth and Planetary Science Letters, 390, 116-127.

Fu, X.G., Wang, J., Zeng, S., Feng, X., Wang, D. and Song, C. 2017. Continental weathering and palaeoclimatic changes through the onset of the Early Toarcian oceanic anoxic event in the Qiangtang Basin, eastern Tethys. Palaeogeogr. Palaeoclimatol. Palaeoecol., 487, 241-250.

Gaillard, C. and Olivero, D. 2009. The ichnofossil Halimedides in cretaceous pelagic deposits from the Alps: environmental and ethological significance. PALAIOS, 24, 257-270.

Gertsch, B., Keller, G., Adatte, T. and Bartels, D. 2011. Trace-Element Geochemistry of Brazos Sections, Texas, U.S.A.. In: Keller, G. and Adatte, T. (eds) End-Cretaceous mass Extinction and Chicxulub impact in Texas: SEPM Special Publication, 100, 251-280.

Gómez, J.J., Goy, A. and Canales, M.L. 2008. Seawater temperature and carbon isotope variations in belemnites linked to mass extinction during the Toarcian (Early Jurassic) in Central and Northern Spain. Comparison with other European sections. Palaeogeogr. Palaeoclimatol. Palaeoecol., 258, 28-58, http://dx.doi.org/10.1016/i.palaeo.2007.11.005

Grasby, S. E., Sanei, H., Beauchamp, B. and Chen, Z. H. 2013. Mercury deposition through the Permo-Triassic biotic crisis. Chemical Geology, 351, 209-216.

Grasby, S.E., Them II, T.R., Chen, Z., Yin, R. and Ardakani, O.H. 2019. Mercury as a proxy for volcanic emissions in the geologic record. Earth Sci. Rev., 196, 1-16. 
Guex, J., Morard, A., Bartolini, A. and Morettini, E. 2001. Discovery of an important stratigraphic gap at the Domerian-Toarcian limit: Palaeo-oceanographic implications. Bull. Soc. Vaudoise Sci. Nat., 87, 277-284.

Harazim, D., van de Schootbrugge, B., Sorichter, K., Fiebig, J., Weug, A., Suan, G. and Oschmann, W. 2013. Spatial variability of watermass conditions within the European Epicontinental Seaway during the Early Jurassic (PliensbachianToarcian). Sedimentology, 60, 359-390. http://dx.doi.org/10.1111/j.13653091.2012.01344.X.

Hauff B. and Hauff, R. B. 1981. Das Holzmadenbuch. Hauff Museum, Holzmaden, 136 pp.

Hermoso, M. and Pellenard, P. 2014. Continental weathering and climatic changes inferred from clay mineralogy and paired carbon isotopes across the early to middle Toarcian in the Paris Basin. Palaeogeogr. Palaeoclimatol. Palaeoecol., 399, 385-393.

Hermoso, M., Minoletti, F. and Pellenard, P. 2013. Black shale deposition during Toarcian super-greenhouse driven by sea level. Climate of the Past, 9, 2703-2712.

Hesselbo, S.P., Grocke, D.R., Jenkyns, H.C., Bjerrum, C.J., Farrimond, P., Bell, H.S.M., Green, O.R., 2000. Massive dissociation of gas hydrate during a Jurassic oceanic anoxic event. Nature, 406, 392-395.

Hesselbo, S.P., Jenkyns, H.C., Duarte, L.V. and Oliveira, L.C. 2007. Carbon-isotope record of the Early Jurassic (Toarcian) Oceanic Anoxic Event from fossil wood and marine carbonate (Lusitanian Basin, Portugal). Earth Planet. Sci. Lett., 253 (3-4), 455-470.

Howarth. M.K. 1992. The ammonite family Hildoceratidae in the Lower Jurassic of Britain. Parts 1 and 2. Monograph of the Palaeontological Society, 586 and 590, London, $200 \mathrm{p}$.

Ikeda, M., Hori, R.S., Ikehara, M., Miyashita, R., Chino, M. and Yamada, K. 2018. Carbon cycle dynamics linked with Karoo-Ferrar volcanism and astronomical cycles during Pliensbachian-Toarcian (Early Jurassic). Glob. Planet. Chang., 170, 163171.

Ivanov, A.V., Meffre, S., Thompson, J., Corfu, F., Kamenetsky, V.S., Kamenetsky, M.B. and Demonterova, E.I. 2017. Timing and genesis of the Karoo-Ferrar large igneous province: new high precision U-Pb data for Tasmania confirm short duration of the major magmatic pulse. Chem. Geol., 455, 32-43. 
Izumi, K., Kemp, D.B., Itamiya, S. and Inui, M. 2018. Sedimentary evidence for enhanced hydrological cycling in response to rapid carbon release during the early Toarcian oceanic anoxic event. Earth and Planetary Science Letters, 481, 162-170.

Jenkyns, H.C. 1988. The early Toarcian (Jurassic) anoxic event: Stratigraphic, sedimentary and geochemical evidence. Am. J. Sci., 288, 101-151, http://dx.doi.org/10.2475/ajs.288.2.101

Jenkyns, H.C. and Clayton, C.J. 1986. Black shales and carbon isotopes in pelagic sediments from the Tethyan Lower Jurassic. Sedimentology, 33 (1), 87-106.

Jenkyns, H.C. and Clayton, C.J. 1997. Lower Jurassic epicontinental carbonates and mudstones from England and Wales: chemostratigraphic signals and the early Toarcian anoxic event. Sedimentology, 44 (4), 687-706.

Jourdan, F., Féraud, G., Bertrand, H., Watkeys, M.K. and Renne, P.R. 2008. The 40Ar/39Ar ages of the sill complex of the Karoo large igneous province: Implications for the Pliensbachian-Toarcian climate change. Geochem. Geophys. Geosyst., 9, 1-20.

Kafousia, N., Karakitsios, V., Jenkyns, H.C. and Mattioli, E. 2011. A global event with a regional character: the Early Toarcian Oceanic Anoxic Event in the Pindos Ocean (northern Peloponnese, Greece). Geol. Mag., 148 (4), 619-631.

Keller, G., Berner, Z., Adatte, T. and Stueben, D. 2004. Cenomanian-Turonian d13C and d180, sea level and salinity variations at Pueblo, Colorado. Palaeogeography, Palaeoclimatology, Palaeoecology, 211, 19-43.

Kemp, D.B., Coe, A.L., Cohen, A.S. and Schwark, L. 2005. Astronomical pacing of methane release in the Early Jurassic period. Nature, 437, 396-399. http://dx.doi.org/10.1038/nature04037.

Krencker, F.N., Bodin, S., Suan, G., Heimhofer, U., Kabiri, L. and Immenhauser, A. 2015. Toarcian extreme warmth led to tropical cyclone intensification. Earth Planet. Sci. Lett., 425, 120-130.

Krencker, FN., Lindström, S. and Bodin, S. 2019. A major sea-level drop briefly precedes the Toarcian oceanic anoxic event: implication for Early Jurassic climate and carbon cycle. Sci. Rep., 9, 12518. doi.org/10.1038/s41598-019-48956-x

Kübler, B. 1987. Cristallinité de l'illite, méthodes normalisées de préparations, méthodes normalisées de mesures: Cahiers Institut Géologie de Neuchâtel, Suisse, AD, 1-13.

Kuypers, M. M. M., Pancost, R. D., Nijenhuis, I. A. and Sinninghe Damsté, J. S. 2002. Enhanced productivity led to increased organic carbon burial in the euxinic North 
Atlantic basin during the late Cenomanian oceanic anoxic event. Paleoceanography, 17, doi:10.1029/2000PA000569.

Lindgren, J., Sjövall, P., Thiel, V., Zheng, W., Ito, S., Wakamatsu, K., Hauff, R., Kear, B.P., Engdahl, A., Alwmark, C., Eriksson, M.E., Jarenmark, M., Sachs, S., Ahlberg, P.E., Marone, F., Kuriyama, T., Gustafsson, O., Malmberg, P., Thomen, A., RodríguezMeizoso, I., Uvdal, P., Ojika, M. and Schweitzer, M.H. 2018. Soft-tissue evidence for homeothermy and crypsis in a Jurassic ichthyosaur. Nature, 564, 359-365.

Mailliot, S., Mattioli, E., Bartolini, A., Baudin, F., Pittet, B. and Guex, J. 2009. Late Pliensbachian-Early Toarcian (Early Jurassic) environmental changes in an epicontinental basin of NW Europe (Causses area, central France): a micropaleontological and geochemical approach. Palaeogeogr. Palaeoclimatol. Palaeoecol., 273, 346-364.

Martill, D.M. 1993. Soupy substrates: a medium for the exceptional preservation of ichthyosaurs of the Posidonia Shale (Lower Jurassic) of Germany. Kaupia, 2, 7797.

Martin, J.E., Suan, G., Suchéras-Marx, B., Rulleau, L., Janneau, K., Williams, M., Léna, A., Grosjean, A.-S., Sarroca, E., Perrier, V., Charruault, A., Maxwell, E. and Vincent, P. (this volume) Stenopterygiids from the lower Toarcian of Beaujolais and a chemostratigraphic context for ichthyosaur preservation during the Toarcian Oceanic Anoxic Event.

Martindale, R.C., Them, T.R., II, Gill, B.C., Marroquín, S.M. and Knoll, A.H. 2017. A new Early Jurassic (ca. 183 Ma) fossil Lagerstätte from Ya Ha Tinda, Alberta, Canada. Geology, 45, 255-258.

Mattioli, E., Pittet, B., Bucefalo Palliani, R., Röhl, H.J., Schmid-Röhl, A. and Morettini, E. 2004. Phytoplankton evidence for the timing and correlation of palaeoceanographical changes during the early Toarcian oceanic anoxic event (Early Jurassic). J. Geol. Soc. Lond., 161 (4), 685-693.

Mattioli, E., Pittet, B., Petitpierre, L. and Mailliot, S. 2009. Dramatic decrease of pelagic carbonate production by nannoplankton across the Early Toarcian anoxic event (T-OAE). Glob. Planet. Change,

65, 134-145, http://dx.doi.org/10.1016/j.gloplacha.2008.10.018. 
Maxwell, E.E., Vincent, P., 2016. Effects of the early Toarcian Oceanic Anoxic Event on ichthyosaur body size and faunal composition in the Southwest German Basin. Paleobiology, 42, 117-126.

McArthur, J.M. 2019. Early Toarcian black shales: a response to an oceanic anoxic event or anoxia in marginal basins? Chem. Geol., 522, 71-83.

McArthur, J.M., Algeo, T.J., van de Schootbrugge, B., Li, Q. and Howarth, R.J. 2008. Basinal restrictions, black shales, Re-Os dating, and the early Toarcian (Jurassic) oceanic anoxic event. Paleoceanography, 23 (4).

McLennan, S. M. 1993. Weathering and global denudation. Journal of Geology, 101, 295303.

Meister, C. 1989. Les ammonites du Domérien des Causses (France). Cahier de paléontologie, CNRS Publ., Paris, 98 p.

Montero-Serrano, J.-C., Föllmi, K.B., Adatte, T., Spangenberg, J.E., Tribovillard, N., Fantasia, A., Suan, G., 2015. Continental weathering and redox conditions during the early Toarcian Oceanic Anoxic Event in the northwestern Tethys: Insight from the Posidonia Shale section in the Swiss Jura Mountains. Palaeogeography, Palaeoclimatology, Palaeoecology, 429, 83-99.

Morard, A. 2004. Les événements du passage Domérien-Toarcien entre Téthys occidentale et Europe du Nord-Ouest. PhD thesis, Université Lausanne, Géologie Paléontologie, 1-158.

Morard, A., Guex, J., Bartolini, A., Morettini, E. and de Wever, P. 2003. A new scenario for the Domerian-Toarcian transition. Bull. Soc. Géol. Fr., 174 (4), 351-356, http://dx.doi.org/10.2113/174.4.351.

Müller, T., Jurikova, H., Gutjahr, M., Toma`sových, A., Schlögl, J., Liebetrau, V., Duarte, L.V., Milovsky, R., Suan, G., Mattioli, E., Pittet, B. and Eisenhauer, A. 2020. Ocean acidification during the early Toarcian extinction event. Geology, 48(12), 11841188. https://doi. org/10.1130/G47781.1.

Nesbitt, H. W. and Young, G.M. 1989. Formation and diagenesis of weathering profiles. Journal of Geology, 97, 129-147.

Nesbitt, H.W. and Young, G.M. 1982. Early Proterozoic climates and plate motions inferred from major element chemistry of lutites. Nature, 299, 715-717. 
Pálfy, J. and Smith, P.L. 2000. Synchrony between Early Jurassic extinction, oceanic anoxic event, and the Karoo-Ferrar flood basalt volcanism. Geology, 28 (8), 747750.

Pálfy, J., Mortensen, J.K., Smith, P.L., Friedman, R.M., McNicoll, V., Villeneuve, M., 2000. New $\mathrm{U}-\mathrm{Pb}$ zircon ages integrated with ammonite biochronology from the Jurassic of the Canadian Cordillera. Canadian Journal of Earth Science, 37, 549-567.

Parker, A. 1970. An index of weathering for silicate rocks. Geological Magazine, 107, 501-504.

Percival, L.M.E., Cohen, A.S., Davies, M.K., Dickson, A.J., Hesselbo, S.P., Jenkyns, H.C., Leng, M.J., Mather, T.A., Storm, M.S. and Xu, W. 2016. Osmium isotope evidence for two pulses of increased continental weathering linked to Early Jurassic volcanism and climate change. Geology, 44 (9), 759-762.

Percival, L.M.E., Witt, M.L.I., Mather, T.A., Hermoso, M., Jenkyns, H.C., Hesselbo, S.P., AlSawaidi, Storm, M.S., Xu, W. and Ruhl, M. 2015. Globally enhanced mercury deposition during the end-Pliensbachian extinction and Toarcian OAE: a link to the Karoo-Ferrar Large Igneous Province. Earth Planet. Sci. Lett., 428, 267-280.

Philippe, M., Puijalon, S., Suan, G., Mousset, S., Thévenard, F. and Mattioli, E. 2017. The palaeolatitudinal distribution of fossil wood genera as a proxy for European Jurassic terrestrial climate. Palaeogeography, Palaeoclimatology, Palaeoecology, 466, 373-381.

Pinard, J., Weis, R., Neige, P., Mariotti, N. and Cencio, A.D., 2014. Belemnites from the Upper Pliensbachian and the Toarcian (Lower Jurassic) of Tournadous (Causses, France). N. Jb. Geol. Paläont. Abh., 273 (2), 155-177. http://dx.doi.org/10.1127/0077-7749/2014/0421.

Price, J.R. and Velbel, M.A. 2003. Chemical weathering indices applied to weathering profiles developed on heterogeneous felsic metamorphic parent rocks. Chemical Geology, 202, 397-416.

Rampino, M. R., Rodriguez, S., Baransky, E. and Cai, Y. 2017. Global nickel anomaly links Siberian Traps eruptions and the latest Permian mass extinction. Nature Scientific Reports, 7, 12416.

Redfield, A.C. 1958. The biological control of chemical factors in the environment. Am. Sci., 46, 205-222. 
Remírez, M., Algeo, T.J., 2020a. Paleosalinity proxy evidence for watermass restriction in the Cleveland Basin (UK) during the Toarcian OAE. Earth Sci. Rev., 209, 103072.

Remírez, M.N. and Algeo, T.J. 2020b. Carbon cycle changes during the Toarcian (early Jurassic) and implications for regional versus global drivers of the Toarcian oceanic anoxic event. Earth Sci. Rev., 209, 103283, https://doi.org/10.1016/j.earscirev.2020.103283

Riegraf, W., Werner, G. And Lörcher, F. 1984. Der Posidonienschiefer: Biostratigraphie Fauna und Fazies des südwestdeutschen Untertoarciums (Lias Epsilon). Stuttgart: Enke.

Riquier, L., Tribovillard, N., Averbuch, O., Devleeschouwer, X. and Riboulleau, A. 2006. The Late Frasnian Kellwasser horizons of the Harz Mountains (Germany): two oxygen deficient periods resulting from different mechanisms. Chemical Geology, 233, 137-155.

Rodríguez-Tovar, F.J., Miguez-Salas, O., Dorador, J. and Duarte, L.V. 2019. Opportunistic behaviour after the Toarcian Oceanic Anoxic Event: the trace fossil Halimedides. Palaeogeogr. Palaeoclimatol. Palaeoecol., 520, 240-250.

Röhl, J., Schmid-Röhl, A., Oschmann, O., Frimmel, A. and Schwark, L., 2001. The Posidonia Shale (Lower Toarcian) of SW-Germany: an oxygen-depleted ecosystem controlled by sea level and palaeoclimate. Palaeogeogr. Palaeoclimatol. Palaeoecol., 165, 27-52.

Rosales, I., Quesada, S. and Robles, S. 2006. Geochemical arguments for identifying second-order sea-level changes in hemipelagic carbonate ramp deposits. Terra Nova, 18, 233-240.

Ruebsam, W. and Al-Husseini, M. 2020. Calibrating the Early Toarcian (Early Jurassic) with stratigraphic black holes (SBH). Gondwana Research, 82, 317-336.

Ruebsam, W., Mayer, B. and Schwark, L. 2019. Cryosphere carbon dynamics control early Toarcian global warming and sea level evolution. Global and Planetary Change, 172, 440-453.

Ruebsam, W., Reolid, M., Sabatino, N., Masetti, D. and Schwark, L. 2020. Molecular paleothermometry of the early Toarcian climate perturbation. Global and Planetary Change, 195, 103351.

Ruvalcaba Baroni, I., Pohl, A., Helmond, N.A.G.M., Papadomanolaki, N.M., Coe, A.L., Cohen, A.S., Schootbrugge, B., Donnadieu, Y. and Slomp, C.P. 2018. Ocean Circulation in 
the Toarcian (Early Jurassic): A Key Control on Deoxygenation and Carbon Burial on the European Shelf. Paleoceanography and Paleoclimatology, 33, 994-1012.

Sander, P.M. and Bucher, H. 1993. An ichthyosaur from the uppermost Toarcian of southern France. Neues Jahrbuch für Geologie und Paläontologie-Monatshefte, 631-640.

Sanei, H., Grasby, S.E. and Beauchamp, B. 2012. Latest Permian mercury anomalies. Geol. Soc. Am., 40, 63-66.

Schlanger, S. O. and Jenkyns, H. C. 1976. Cretaceous oceanic anoxic events: Causes and consequences. Geol. Mijnbouw, 55, 179-184.

Schoepfer S. D., Shen J., Wei H., Tyson R. V., Ingall E. and Algeo T. J. 2015. Total organic carbon, organic phosphorus, and biogenic barium fluxes as proxies for paleomarine productivity. Earth Sci. Rev., 149, 23-52.

Schöllhorn, I., Adatte, T., Charbonnier, G., Mattioli, E., Spangenberg, J. E. and Föllmi, K. B. 2020. Pliensbachian environmental perturbations and their potential link with volcanic activity: Swiss and British geochemical records. Sedimentary Geology, 406, 105665. 10.1016/j.sedgeo.2020.105665.

Schouten, S., van Kaam-Peters, H.M., Rijpstra, W.I.C., Schoell, M.and Sinninghe Damsté, J.S. 2000. Effects of an oceanic anoxic event on the stable carbon isotopic composition of early Toarcian carbon. Am. J. Sci., 300 (1), 1-22.

Sciau, J., Crochet, J.Y. and Mattei, J. 1990. Le premier squelette de Plesiosaure de France sur le Causse du Larzac (Toarcien, Jurassique inférieur). Géobios, 23(1), pp.111116.

Sell, B., Ovtcharova, M., Guex, J., Bartolini, A., Jourdan, F., Spangenberg, J.E., Vicente, J.-C. and Schaltegger, U. 2014. Evaluating the temporal link between the Kaoo LIP and climatic-biologic events of the Toarcian Stage with high-precision U-Pb geochronology. Earth Planet. Sci. Lett., 408, 48-56.

Shen, J., Algeo, T.J., Chen, J., Planavsky, N.J., Feng, Q., Yu, J. and Liu, J. 2019. Mercury in marine Ordovician/Silurian boundary sections of South China is sulphide-hosted and non volcanic in origin. Earth Planet. Sci. Lett., 511, 130-140.

Sial, A.N., Lacerda, L.D., Ferreira, V.P., Frei, R., Marquillas, R.A., Barbosa, J.A., Gaucher, C., Windmoller, C.C. and Pereira, N.S. 2013. Mercury as a proxy for volcanic activity during extreme environmental turnover: the Cretaceous-Paleogene transition. Palaeogeogr. Palaeoclimatol. Palaeoecol., 387, 153-164. 
Slater, S.M., Twitchett, R.J., Danise, S. and Vajda, V. 2019. Substantial vegetation response to Early Jurassic global warming with impacts on oceanic anoxia. Nature Geoscience, 12, 462-467.

Suan, G., 2005. Mise en place de l'événement anoxique du Toarcien: Essai de réévaluation du signal isotopique $\left(\delta^{18} 0\right.$ et $\left.\delta^{13} \mathrm{C}\right)$ et nouvelles données sur coquilles de brachiopodes et carbonates, UFR Sciences Terre Lyon. Université Claude Bernard Lyon 1, Lyon, p. 43.

Suan, G., Mattioli, E., Pittet, B., Lécuyer, C., Suchéras-Marx, B., Duarte, L.V., Philippe, M., Reggiani, L. and Martineau, F. 2010. Secular environmental precursors to Early Toarcian (Jurassic) extreme climate changes. Earth Planet. Sci. Lett., 290 (3-4), 448-458.

Suan, G., Mattioli, E., Pittet, B., Mailliot, S. and Lécuyer, C. 2008a. Evidence for major environmental perturbation prior to and during the Toarcian (Early Jurassic) oceanic anoxic event from the Lusitanian Basin, Portugal. Paleoceanography, 23, PA1202, http://dx.doi.org/10.1029/2007PA001459

Suan, G., Nikitenko, B.L., Rogov, M.A., Baudin, F., Spangenberg, J.E., Knyazev, V.G., Glinskikh, L.A., Goryacheva, A.A., Adatte, T., Riding, J.B., Föllmi, K.B., Pittet, B., Mattioli, E. and Lécuyer, C. 2011. Polar record of Early Jurassic massive carbon injection. Earth Planet. Sci. Lett., 312 (1-2), 102-113.

Suan, G., Pittet, B., Bour, I., Mattioli, E., Duarte, L.V., Mailliot, S., 2008b. Duration of the Early Toarcian carbon isotope excursion deduced from spectral analysis: Consequence for its possible causes. Earth and Planetary Science Letters, 267, 666-679.

Suan, G., Rulleau, L., Mattioli, E., Suchéras-Marx, B., Rousselle, B., Pittet, B., Vincent, P., Martin, J.E., Léna, A., Spangenberg, J.E. and Föllmi, K.B. 2013. Paleoenvironmental significance of Toarcian black shales and event deposits from southern Beaujolais, France. Geol. Mag., 150 (4), 728-742.

Suan, G., Schöllhorn, I., Schlögl, J., Segit, T., Mattioli, E., Lécuyer, C. and Fourel, F. 2018. Euxinic conditions and high sulfur burial near the European shelf margin (Pieniny Klippen Belt, Slovakia) during the Toarcian oceanic anoxic event. Global and Planetary Change, 170, 246-259. 
Suan, G., van De Schootbrugge, B., Adatte, T., Fiebig, J. and Oschmann, W. 2015. Calibrating the magnitude of the Toarcian carbon cycle perturbation. Paleoceanography, 30 (5), 495-509.

Sun, X. and Turchyn, A.V. 2014. Significant contribution of authigenic carbonate to marine carbon burial. Nat. Geosci., 7, 201-204. http://dx.doi.org/10.1038/ngeo2070.

Svensen, H., Planke, S., Chevallier, L., Malthe-Sørenssen, A., Corfu, F. and Jamtveit, B. 2007. Hydrothermal venting of greenhouse gases triggering Early Jurassic global warming. Earth and Planetary Science Letters, 256, 554-566.

Them II, T.R., Gill, B.C., Caruthers, A.H., Gröcke, D.R., Tulsky, E.T., Martindale, R.C., Poulton, T.P. and Smith, P.L. 2017a. High-resolution carbon isotope records of the Toarcian Oceanic Anoxic Event (Early Jurassic) from North America and implications for the global drivers of the Toarcian carbon cycle. Earth and Planetary Science Letters, 459, 118-126.

Them II, T.R., Gill, B.C., Selby, D., Gröcke, D.R., Friedman, R.M., and Owens, J.D. 2017b. Evidence for rapid weathering response to climatic warming during the Toarcian Oceanic Anoxic Event. Scientific Reports, 7, 5003.

Them II, T.R., Jagoe, C.H., Caruthers, A.H., Gill, B.C., Grasby, S.E., Gröcke, D.R., Yin, R. and Owens, J.D. 2019. Terrestrial sources as the primary delivery mechanism of mercury to the oceans across the Toarcian Oceanic Anoxic Event (Early Jurassic). Earth and Planetary Science Letters, 507, 62-72.

Thierry, J., et al. 2000. Middle Toarcian. In: Dercourt, J., Gaetani, M., Vrielynck, B., Barrier, E., Biju-Duval, B., Brunet, M.-F., Cadet, J.P., Crasquin, S. and Sandulescu, M. (eds) Atlas Peri-Tethys Paleogeographical Maps. vol. I-XX.CCGM/CGMW Paris, map 8, (40 co-authors).

Trümpy, D.M. 1983. Le Lias Moyen et Supérieur des Grands Causses et de la région de Rodez: contributions stratigraphiques, sédimentologiques et géochimiques à la connaissance d'un bassin à sédimentation marneuse. Cahiers de l'Université, Université de Pau et des Pays de l'Adour, 19, 1-363.

Uchman, A. 1998. Taxonomy and ethology of flysch trace fossils: a revision of the Marian Książkiewicz collection and studies of complementary material. Ann. Soc. Geol. Pol., 68, 105-218. 
Uchman, A. 1999. Ichnology of the Rhenodanubian flysch (Lower Cretaceous-Eocene) in Austria and Germany. Beringeria, 25, 65-171.

Uchman, A., Rodríguez-Tovar, F.J. and Oszczypko, N. 2013. Exceptionally favourable life conditions for macrobenthos during the late Cenomanian OAE-2 event: ichnological record from the Bonarelli Level in the Grajcarek Unit, Polish Carpathians. Cretac. Res., 46, 1-10.

Ullmann, C.V., Boyle, R., Duarte, L.V., Hesselbo, S.P., Kasemann, S.A., Klein, T., Lenton, T.M., Piazza, V. and Aberhan, M. 2020. Warm afterglow from the Toarcian Oceanic Anoxic Event drives the success of deep-adapted brachiopods. Scientific Reports, 10,6549 .

Urlichs, M., Wild, R. and Ziegler, B. 1994. Der Posidonien-Schiefer und seine Fossilien. Stuttgarter Beiträge zur Naturkunde C, 36, 1-95.

van de Schootbrugge, B., Houben, A.J.P., Ercan, F.E.Z., Verreussel, R., Kerstholt, S., Janssen, N.M.M., Nikitenko, B. and Suan, G. 2020. Enhanced Arctic-Tethys connectivity ended the Toarcian Oceanic Anoxic Event in NW Europe. Geological Magazine, 119.

Vincent, P., Martin, J., Fischer, V., Suan, G., Khalloufi, B., Suchéras-Marx, B, A. Léna , Janneau, K., Rousselle, B. and Rulleau, L. 2013. Marine vertebrate remains from the Toarcian-Aalenian succession of southern Beaujolais, Rhône, France. Geological Magazine, 150(5), 822-834. doi:10.1017/S0016756812000982

Wang, Y., Ossa Ossa, F., Wille, M., Schurr, S., Saussele, M.-E., Schmid-Röhl, A., Schoenberg, R., 2020. Evidence for local carbon-cycle perturbations superimposed on the Toarcian carbon isotope excursion. Geobiology, 18, 682-709.

Wedepohl, K.H. 1971. Environmental influences on the chemical composition of shales and clays. Physics and Chemistry of the Earth, 8, 305-333.

Wei, W. and Algeo, T.J. 2020. Elemental proxies for paleosalinity analysis of ancient shales and mudrocks. Geochim. Cosmochim. Acta., 287, 341-366. https://doi.org/10.1016/j.gca.2019.06.034.

Wignall, P.B., Newton, R.J. and Little, C.T. 2005. The timing of paleoenvironmental change and cause-and-effect relationships during the Early Jurassic mass extinction in Europe. Am. J. Sci., 305 (10), 1014-1032.

Yan, D., Chen, D., Wang, Q. and Wang. J. 2010. Large-scale climatic fluctuations in the latest Ordovician on the Yangtze block, south China. Geology, 38 (7), 599-602. 


\section{Figures captions}

Table 1: $F_{\text {detrital values }}$ (in $\mathrm{g} / \mathrm{cm}^{2} / \mathrm{ky}$ ) used for the three sites of the Grands Causes Basin. 